
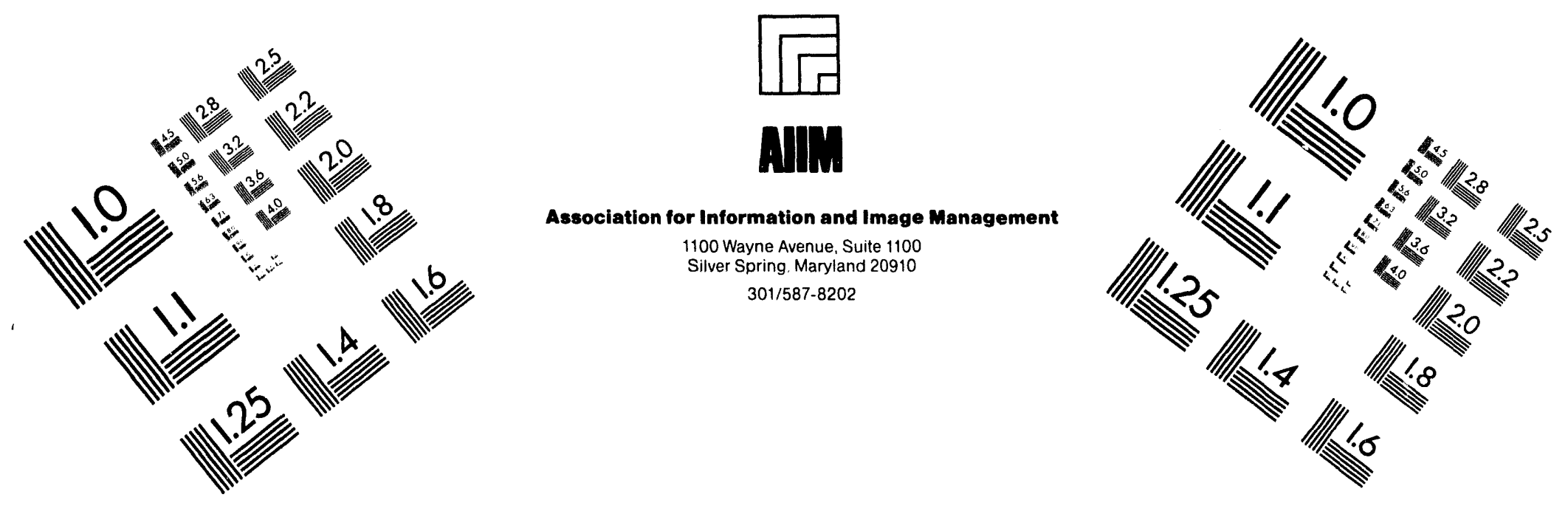

\title{
Centimeter
}

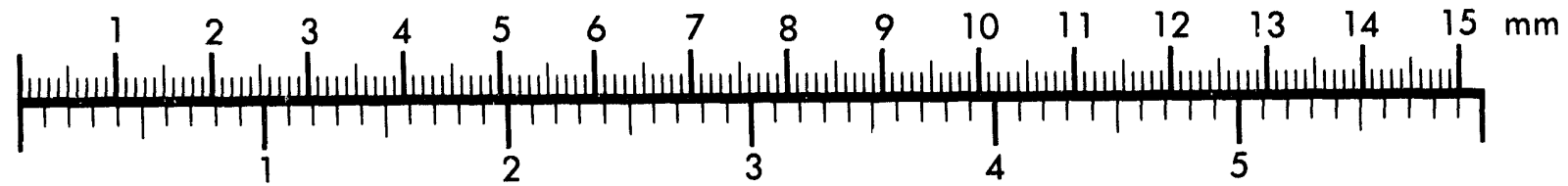
Inches
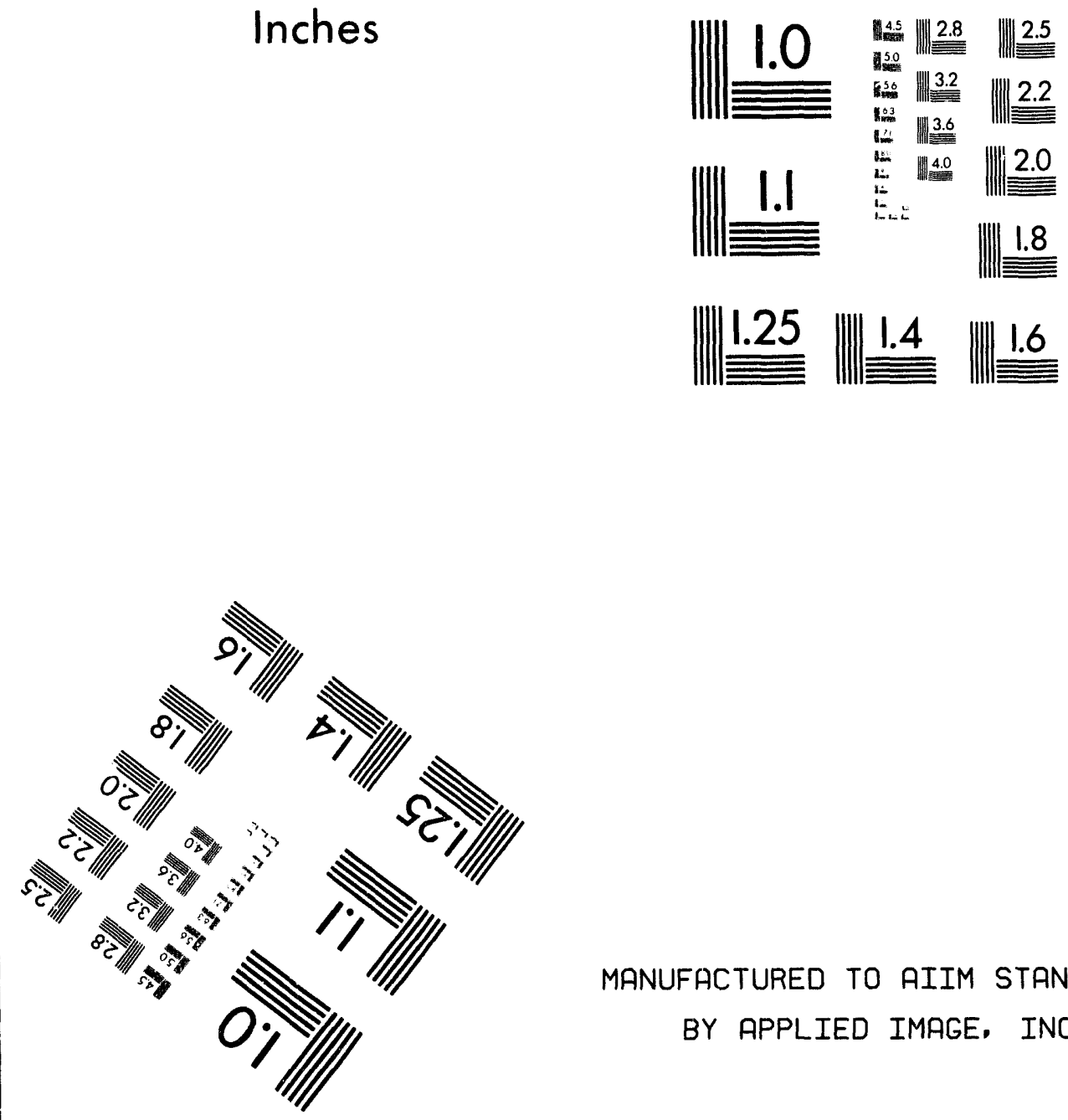

MANUFACTURED TO AIIM STANDARDS

BY APPLIED IMAGE. INC.

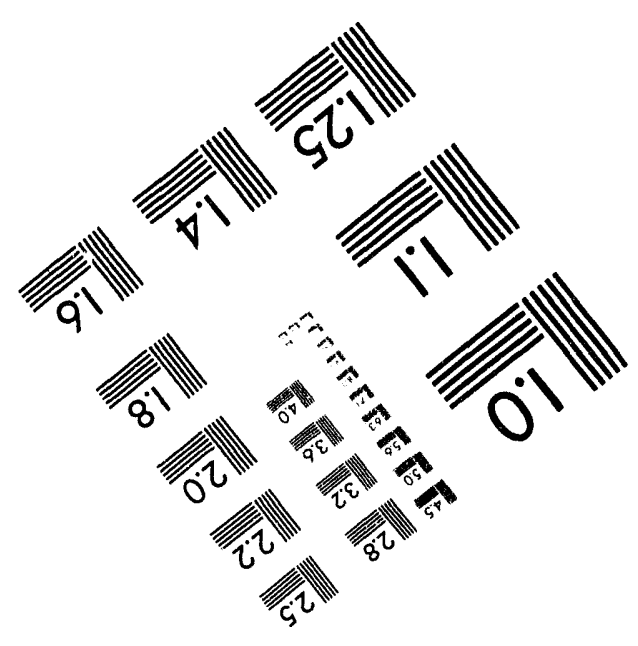



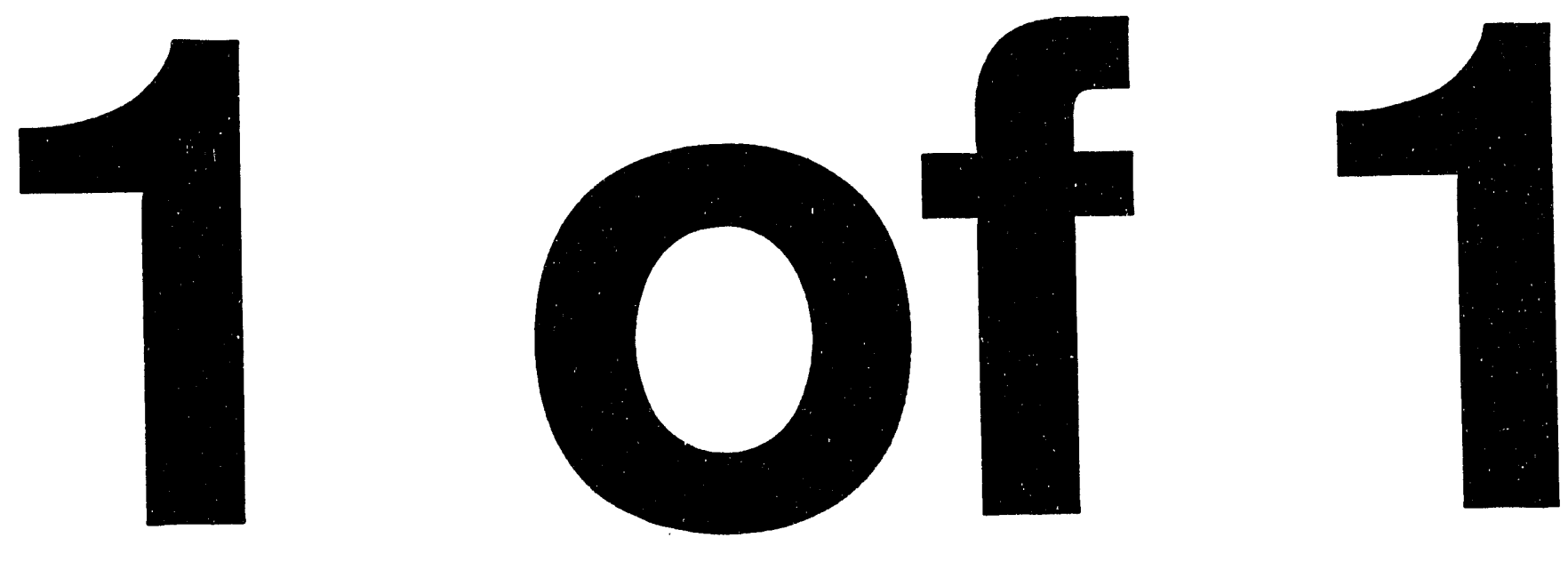


\title{
WASTE MINIMIZATION AND POLLUTION PREVENTION AWARENESS PLAN
}

\author{
Prepared for \\ DOE Nevada Operations Office \\ Las Vegas, Nevada
}

Prepared by

DOE/NV Waste Minimization Task Force

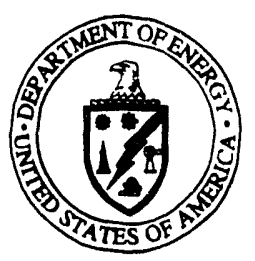

Work Performed Under Contract No.

DE-AC08-92NV10972

August 1994 


\section{WFSTE MINIMIZATION AND POLLUTION \\ PREVENTION AWARENESS PLAN}

NEVADA TEST SITE, NEVADA

Prepared for

DOE Nevada Operations Office

Las Vegas, Nevada

DOE/NV Program Manager A. P. Colarusso

Prepared by

DOE/NV Waste Minimization Task Force

Approved:

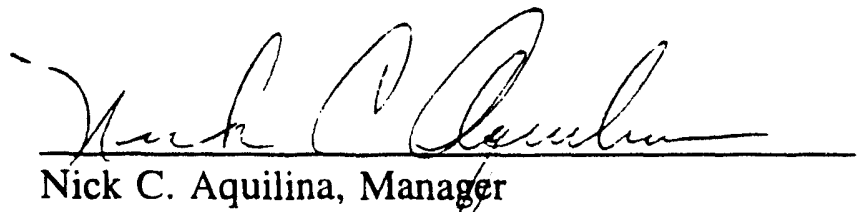

Nevada Operations Office

Date:

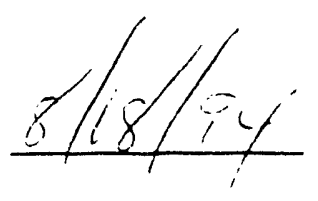

Approved: $t_{\text {osgeh }} 7.7$ core

Joseph N. Fiore, Acting Assistant Manager for

Date:

$8 / 17 / 94$ Environmental Restoration and Waste

Management Division

Approved:

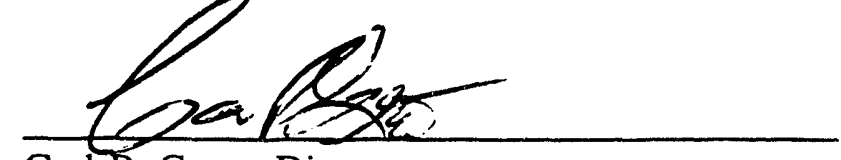

Carl P. Gertz, Director

Waste Management Division

Date: $E 3 / 10 / 54$ 


\section{Table of Contents}

List of Figures $\ldots \ldots \ldots \ldots \ldots \ldots \ldots \ldots \ldots \ldots \ldots \ldots \ldots \ldots$

List of Tables $\ldots \ldots \ldots \ldots \ldots \ldots \ldots \ldots \ldots \ldots \ldots \ldots \ldots \ldots$

List of Acronyms and Abbreviations $\ldots \ldots \ldots \ldots \ldots \ldots$

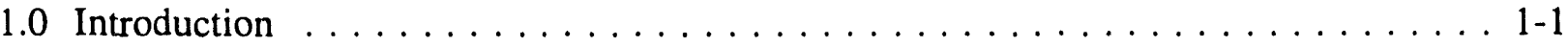

1.1 Mission and Site Description $\ldots \ldots \ldots \ldots \ldots \ldots \ldots \ldots \ldots \ldots \ldots \ldots \ldots \ldots$

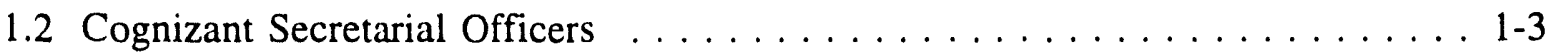

1.3 Purpose and Objectives ...................... 1-3

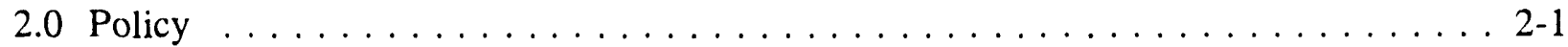

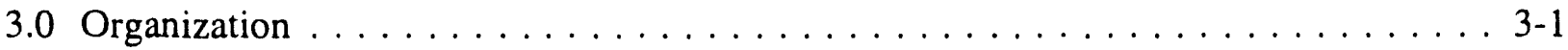

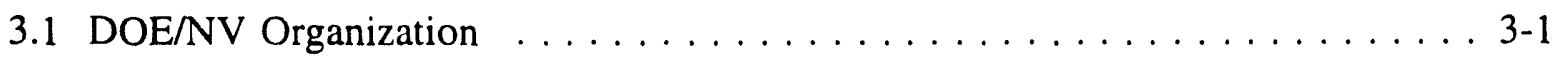

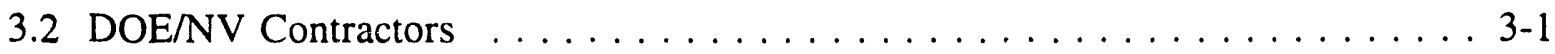

3.3 Waste Minimization and Pollution Program Organization . . . . . . . . 3-2

4.0 Goals . . . . . . . . . . . . . . . . . . . . . . . . . . . . 4-1

4.1 Emergency Planning and Community Right-to-Know Act Goals . . . . . . . . . . 4-1

4.2 Other Waste Reduction and Pollution Prevention Goals . . . . . . . . . . . . . 4-2

4.3 Programmatic Goals . . . . . . . . . . . . . . . . . . . . . 4-5

4.3.1 Decrement Level Funding . . . . . . . . . . . . . . . . . 4-6

4.3.1.1 Waste Minimization and Pollution Program Organization and Infrastructure $\ldots \ldots \ldots \ldots \ldots \ldots \ldots \ldots \ldots \ldots \ldots$

4.3.1.2 Program Development . . . . . . . . . . . . . . . . . 4-7

4.3.1.3 Employee Involvement . . . . . . . . . . . . . 4-7

4.3.1.4 Tracking . . . . . . . . . . . . . . . . . 4-8

4.3.1.5 Reporting . . . . . . . . . . . . . . . . . . 4-8

4.3.1.6 Establish Site-wide Source Reduction and Recycling Programs . . 4-8

4.3.1.7 Technical Assistance . . . . . . . . . . . . . . . . . . . . . 4-9

4.3.1.8 Information and Technology Exchange . . . . . . . . . . . 4-9

4.3.1.9 Program Evaluation . . . . . . . . . . . . . . . . 4-9 


\section{Table of Contents (Continued)}

4.3.2 Target- and Planning-Level Funding . . . . . . . . . . . 4-10

4.3.2.1 Waste Minimization and Pollution Program Organization and Infrastructure $\ldots \ldots \ldots \ldots \ldots \ldots \ldots \ldots \ldots$. 4.10

4.3.2.2 Program Development .................... 4-10

4.3.2.3 Employee Involvement $\ldots \ldots \ldots \ldots \ldots \ldots \ldots \ldots \ldots .44-11$

4.3.2.4 Tracking $\ldots \ldots \ldots \ldots \ldots \ldots \ldots \ldots \ldots \ldots \ldots \ldots .4 .11$

4.3.2.5 Reporting $\ldots \ldots \ldots \ldots \ldots \ldots \ldots \ldots \ldots \ldots \ldots \ldots .4 .12$

4.3.2.6 Establish Site-wide Source Reduction and Recycling Programs . 4-12

4.3.2.7 Technical Assistance . . . . . . . . . . . . . . . . . . . . . . 4-13

4.3.2.8 Information and Technology Exchange . . . . . . . . . 4-13

4.3.2.9 Prog:am Evaluation . . . . . . . . . . . . . . . . 4-14

5.0 Waste Minimization and Pollution Program Status,

Activities, and Resource Requirements $\ldots \ldots \ldots \ldots \ldots \ldots \ldots \ldots \ldots$ 5.'

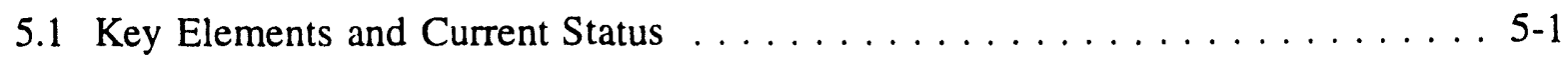

5.1 .1 Organization and Infrastructure $\ldots \ldots \ldots \ldots \ldots \ldots \ldots \ldots \ldots . \ldots \ldots$

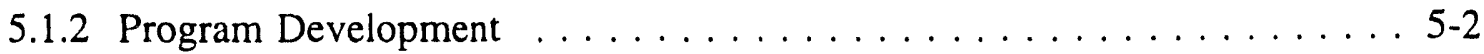

5.1 .3 Employee Involvement $\ldots \ldots \ldots \ldots \ldots \ldots \ldots \ldots \ldots \ldots \ldots \ldots$

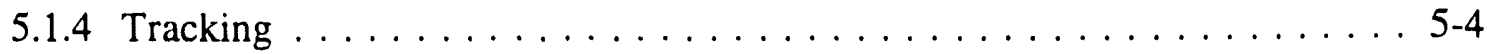

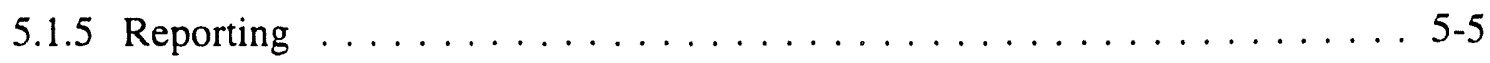

5.1 .6 Site-wide Reduction Programs $\ldots \ldots \ldots \ldots \ldots \ldots \ldots \ldots \ldots \ldots . \ldots \ldots$

5.1 .7 Technical Assistance $\ldots \ldots \ldots \ldots \ldots \ldots \ldots \ldots \ldots \ldots . \ldots \ldots$

5.1.8 Information and Technology Exchange $\ldots \ldots \ldots \ldots \ldots \ldots \ldots \ldots$ 5-7

5.1 .9 Program Evaluation $\ldots \ldots \ldots \ldots \ldots \ldots \ldots \ldots \ldots \ldots \ldots \ldots$

5.2 Planned Activities . . . . . . . . . . . . . . . . . . . . . 5-8

5.2 .1 Organization and Infrastructure $\ldots \ldots \ldots \ldots \ldots \ldots \ldots \ldots \ldots \ldots \ldots$

5.2 .2 Program Development $\ldots \ldots \ldots \ldots \ldots \ldots \ldots \ldots \ldots \ldots \ldots . . \ldots \ldots$

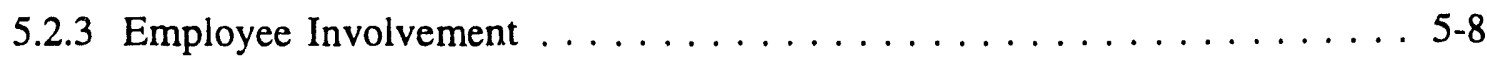

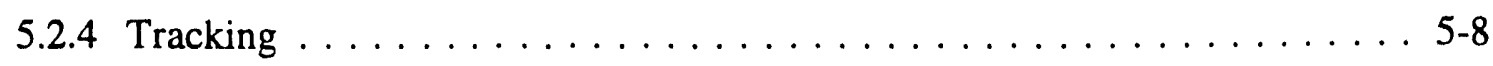

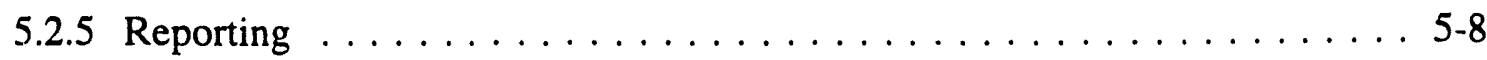

5.2 .6 Source Reduction and Recycling Programs $\ldots \ldots \ldots \ldots \ldots \ldots \ldots$ 5-9

5.2.7 Technical Assistance . . . . . . . . . . . . . . . . . . . . . . 5-9 


\section{Table of Contents (Continued)}

5.2.8 Information and Technology Exchange $\ldots \ldots \ldots \ldots \ldots \ldots \ldots \ldots$ 5-9 $\ldots \ldots$

5.2 .9 Program Evaluation $\ldots \ldots \ldots \ldots \ldots \ldots \ldots \ldots \ldots \ldots \ldots \ldots . \ldots \ldots$

5.3 Outyear Activities . . . . . . . . . . . . . . . . . . . . 5-9

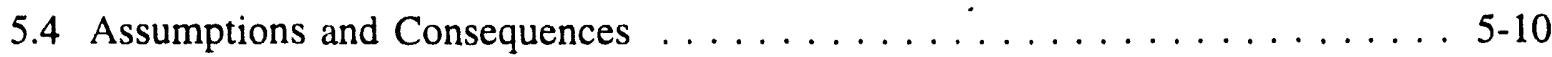

6.0 Site-wide Analysis . . . . . . . . . . . . . . . . . . . . . 6-1

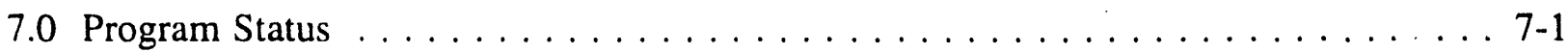

8.0 Generator-Specific Programs and Plans $\ldots \ldots \ldots \ldots \ldots \ldots \ldots \ldots$ 8-1

8.1 Reynolds Electrical \& Engineering Co., Inc. $\ldots \ldots \ldots \ldots \ldots \ldots \ldots \ldots$.1

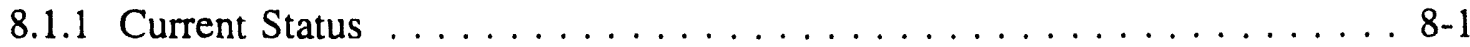

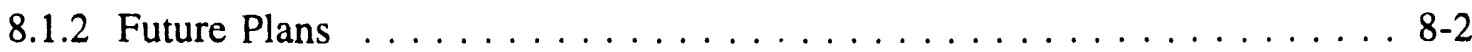

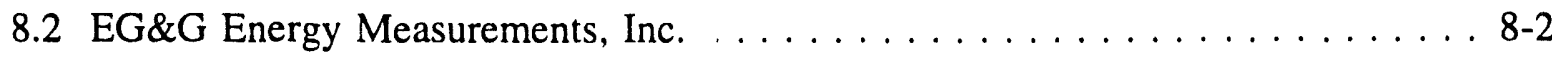

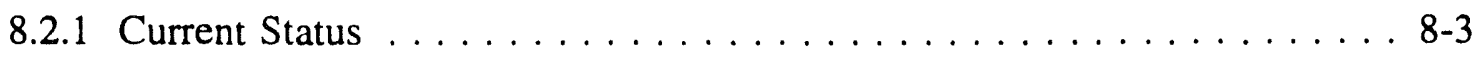

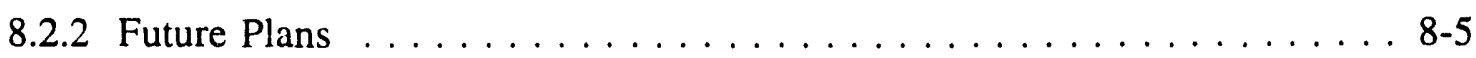

8.3 Raytheon Services Nevada $\ldots \ldots \ldots \ldots \ldots \ldots \ldots \ldots \ldots \ldots \ldots . \ldots .5$

8.3 .1 Current Status $\ldots \ldots \ldots \ldots \ldots \ldots \ldots \ldots \ldots \ldots \ldots \ldots . \ldots \ldots$

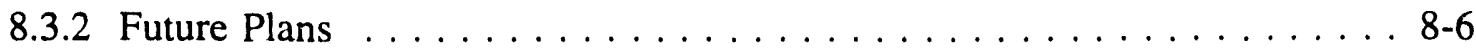

8.4 Wackenhut Services, Inc. . . . . . . . . . . . . . . . . $8-6$

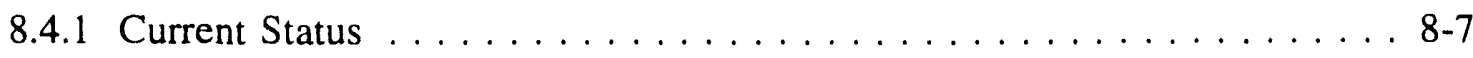

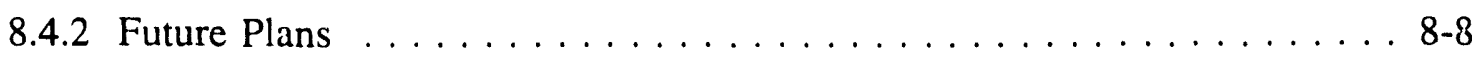

8.5 IT Corporation $\ldots \ldots \ldots \ldots \ldots \ldots \ldots \ldots \ldots \ldots \ldots \ldots \ldots \ldots \ldots$

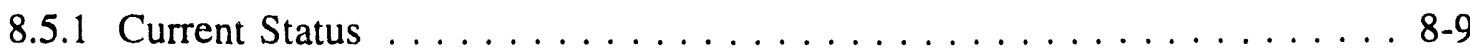

8.5 .2 Future Plans $\ldots \ldots \ldots \ldots \ldots \ldots \ldots \ldots \ldots \ldots \ldots \ldots . \ldots \ldots$

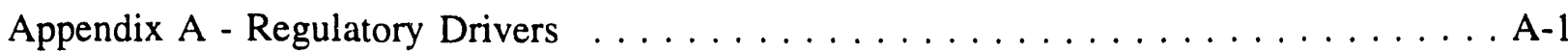

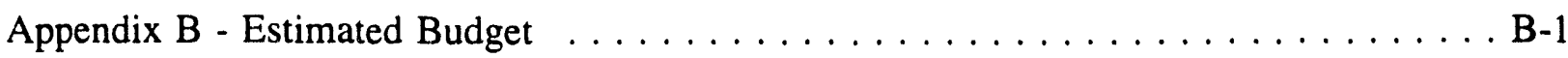

Appendix C - Nevada Waste Minimization Policy $\ldots \ldots \ldots \ldots \ldots \ldots \ldots \ldots$ C-1

Appendix D - Waste Minimization Task Force Charter $\ldots \ldots \ldots \ldots \ldots \ldots \ldots$ D-1 


\section{List of Figures}

Figure Title

Page

1-1 Location of the Nevada Test Site $\ldots \ldots \ldots \ldots \ldots \ldots \ldots \ldots \ldots \ldots . \ldots \ldots$

3-1 Waste Minimization Task Force Organization $\ldots \ldots \ldots \ldots \ldots \ldots$ 3-3

\section{List of Tables}

Table

Title

Page

4-1 Site-wide Quantitative Goals for Reduction of Newly Generated Operations

Waste

$4-3$

4-2 Goals for Each Programmatic Element

4-6 


\section{List of Acronyms and Abbreviations}

ADS

AMEM

DNA

DOE/HQ

DOE/NV

DP

DRI

EG\&G/EM

EM

EPCRA

ERWM

FFCA

FY

HLW

IT

LANL

LLNL

LLW

LLW-M

LVAO

$\mathrm{M} \& \mathrm{O}$

MSDS

NEPA

NTS

NV ERP

PCB

PEIS

$\mathrm{PM} / \mathrm{WSL}$

PPAC

PPOA

RCRA

REECo activity data sheet

Assistant Manager for Environmental Restoration and Waste Management

Defense Nuclear Agency

U.S. Department of Energy Headquarters

U.S. Department of Energy Nevada Operations Office

Defense Programs

Desert Research Institute

EG\&G Energy Measurements, Inc.

Environmental Management

Emergency Planning and Community Right-to-Know Act

Environmental Restoration and Waste Management

Federal Facilities Compliance Act

fiscal year

high-level waste

IT Corporation

Los Alamos National Laboratory

Lawrence Livermore National Laboratory

low-level waste

low-level waste - mixed

Las Vegas Area Operations

Management and Operating

Material Safety Data Sheet

National Environmental Policy Act

Nevada Test Site

Nevada Environmental Restoration Project

polychlorinated biphenyl

Programmatic Environmental Impact Statement

priority material/waste stream list

Pollution Prevention Awareness Committee

Pollution Prevention Opportunity Assessment

Resource Conservation and Recovery Act

Reynolds Electrical \& Engineering Co., Inc. 


$\begin{array}{ll}\text { RSN } & \text { Raytheon Services Nevada } \\ \text { RWMS } & \text { Radioactive Waste Management Site } \\ \text { SAIC } & \text { Science Applications International Corporation } \\ \text { SNL } & \text { Sandia National Laboratories } \\ \text { TRU } & \text { transuranic } \\ \text { TSCA } & \text { Toxic Substances Control Act } \\ \text { USAF } & \text { U.S. Air Force } \\ \text { WMD } & \text { Waste Management Division } \\ \text { WMIN/PP } & \text { waste minimization and pollution program } \\ \text { WSI } & \text { Wackenhut Services, Inc. }\end{array}$




\subsection{Introduction}

The U.S. Department of Energy Nevada Operations Office (DOE/NV) Waste Minimization and Pollution Prevention Awareness Program Plan illustrates the commitment of DOE/NV and contractor management to reduce waste generation and fully comply with state and federal laws and DOE Orders concerning waste minimization and pollution prevention (WMin/PP). The plan formalizes the DOE/NV WMin/PP Program by consolidating completed, ongoing, and planned activities and is compatible with DOE's program initiatives. Guidance provided by both DOE Headquarters (DOE/HQ) Defense Programs (DP) and Environmental Management (EM) has been followed in preparation of this WMin/PP Awareness Program Plan. In addition, the guidance presented in the U.S. Environmental Protection Agency's May 28, 1993, Federal Register notice (Pages 31114 through 31120) was also followed in preparation of this plan.

\subsection{Mission and Site Description}

The primary mission of DOE/NV is to manage and operate the Nevada Test Site (NTS) and other designated test locations, within and outside the United States; provide facilities and services to DOE and non-DOE NTS users; and plan, coordinate, and execute nuclear weapons tests and related test activities. DOE/NV also:

- Supports operations under interagency agreements pertaining to tests, emergencies, and related functions/activities

- Plans, coordinates, and executes environmental restoration

- Provides support to the Yucca Mountain Site Characterization Project Office in conjunction with DOE/HQ oversight

- Manages the Radioactive Waste Management Sites (RWMS) for disposal of low-level and mixed wastes received from the NTS and off-site generators

- Implements waste minimization programs to reduce the amount of hazardous, mixed, radioactive, and nonhazardous solid waste that is generated and disposed

The NTS, which is the primary facility controlled by DOE/NV, occupies 1,350 square miles of restricted-access, federally-owned land located in Nye County in Southern Nevada. The NTS is located in a sparsely populated area, approximately 65 miles northwest of Las Vegas, Nevada (Figure 1-1). 


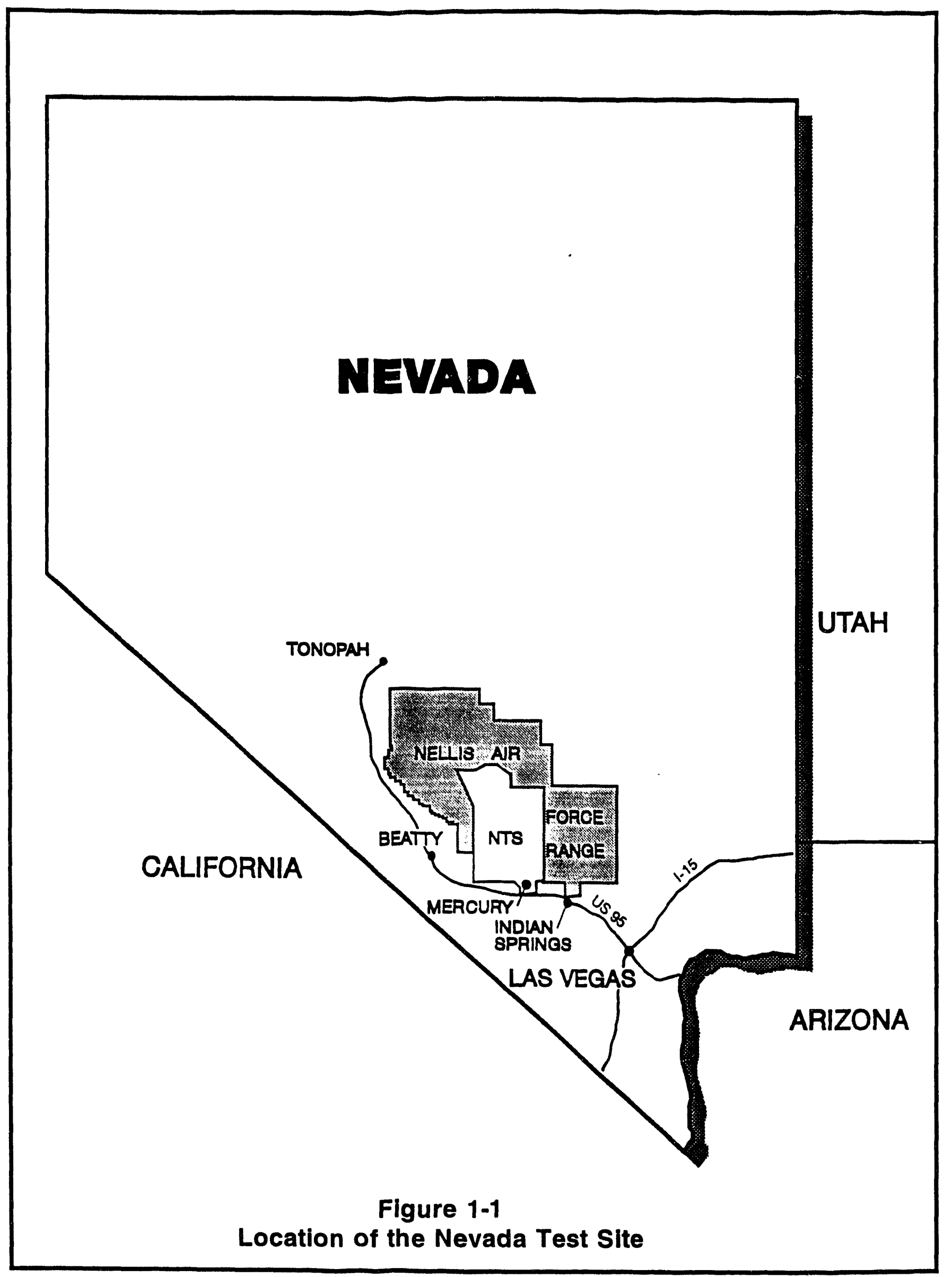


The NTS is used to conduct all United States nuclear weapons tests. These tests are conducted underground, either in veitical holes or horizontal tunnels, for containment of the detonation products. The NTS was chosen in 1950 as the nation's on-continent nuclear weapons testing area because of its climate, low surrounding population density, and minimal risk to public safety and security. The site employs approximately 4,000 people. There are numerous functions that support testing activities, such as vehicle maintenance, painting, carpentry, and machine shops; feeding and housing; and laboratories. Currently, there is a moratorium on nuclear testing. Therefore, the mission of the NTS is to maintain a state of readiness to resume testing if required.

The NTS and several off-site locations are undergoing characterization and remediation as part of the Nevada Environmental Restoration Project (NV ERP). NV ERP subprojects include characterization of the deep aquifers beneath the NTS and various NTS industrial sites. Characterization is also ongoing at off-site former testing locations in Alaska, Colorado, Mississippi, New Mexico, and central Nevada. NV ERP activities may result in the generation of both remedial waste (generally soil and groundwater) and newly-generated secondary waste, such as personal protective equipment, decontamination rinsate, sampling equipment, and analytical sample residue.

\subsection{Cognizant Secretarial Officers}

The Cognizant Secretarial Officers are Defense Programs (DP-1) and Environmental Management (EM-1).

\subsection{Purpose and Objectives}

The purpose of this plan is to establish the requirements of the DOE/NV site-wide WMin/PP Awareness Program, provide guidance for generator-specific WMin/PP Awareness Implementation Plans and Programs, and identify methods and activities that will be employed to reduce the quantity and toxicity of wastes generated at DOE/NV facilities. It is intended to satisfy DOE and other regulatory and legal requirements that are discussed in Appendix A. This plan sets goals for WMin/PP and discusses the funding and resources required to implement the DOE/NV WMin/PP Awareness Program. The primary funding mechanism for WMin/PP activities is through the Activity Data Sheets (ADSs) submitted to DOE HQ. Copies of relevant budget estimates derived from the ADSs are provided in Appendix B. 
This plan is a reference tool and guidance document for managers, operations personnel, and support staff. It contains policy, goals, objectives, and strategy for carrying out the DOE/NV WMin/PP Program. This plan applies to all DOE/NV facilities, contractors, and NTS users. 


\subsection{Policy}

The WMin/PP Program reflects DOE/NV's goals and policies for waste minimization and represents an ongoing effort to make WMin/PP part of NV's operating philosophy. In accordance with DOE policy, an hierarchial approach to waste reduction has been adopted and is applied to all types of waste.

DOE/NV has issued a waste minimization policy statement, which is included as Appendix C. DOE/NV contractors have also issued waste minimization policy statements that are included in the generator-specific implementation plans. These policy statements provide for implementation of an effective WMin/PP program, the elements of the $1993 \mathrm{WMin} / \mathrm{PP}$ Crosscut Plan, and pertinent WMin/PP Executive Orders.

It is the policy of DOE/NV that waste reduction is a primary consideration in research activities, process design, and facility design and operations. DOE/NV is committed to eliminating or reducing the total amount of hazardous, mixed, radioactive, and nonhazardous solid waste it generates. DOE/NV views the WMin/PP Awareness Program as a critical tool that could eliminate or reduce the need for many programs that are currently required to regulate and report waste in the DOE system. DOE/NV recognizes the need for aggressively taking action to protect the environment, protect the workers' health, and present a positive image to the public. $\mathrm{DOE} / \mathrm{NV}$ is proactively monitoring the effects of what has taken place in the past and is correcting deficiencies in present activities. DOE/NV dedication to reduction of waste generation, through tools such as Pollution Prevention Opportunity Assessments (PPOAs), will eliminate and mitigate future problems. 


\subsection{Organization}

\subsection{DOE/NV Organization}

The DOE/NV WMin/PP Program is managed by the Program Manager within the Waste Management Division (WMD) under the Assistant Manager for Environmental Restoration and Waste Management (AMEM). The AMEM is responsible for line management of WMin/PP activities and for ensuring DOE/NV's compliance with regulatory requirements and DOE Orders including responsibilities for policy, programmatic funding, and scheduling decisions. The DOE/NV WMin/PP Program Manager is responsible for providing oversight of contractor WMin/PP activities.

\subsection{DOE/NV Contractors}

There are five principal support contractors utilized by DOE/NV. The contractors and their responsibilities are:

- Reynolds Electrical \& Engineering Co., Inc. (REECo), is the prime support contractor at the NTS and provides construction support, large-diameter drilling and tunneling, food services, housing, industrial safety, medical services, purchasing, fire protection, warehousing, transportation, radiation monitoring, engineering services, and management and operations of the RWMSs. REECo is funded by both DP and EM.

- EG\&G Energy Measurements, Inc. (EG\&G/EM), provides electronics and instrumentation support to the Nuclear Weapons Development Program. EG\&G/EM also provides remote sensing services and support for National Environmental Policy Act (NEPA) biological surveys. EG\&G/EM activities on behalf of DOE/NV are conducted at six locations. $\mathrm{EG} \& \mathrm{G} / \mathrm{EM}$ is funded by both DP and EM.

- Raytheon Services Nevada (RSN) provides architectural and engineering (A\&E) support services for construction, drilling, and mining activities and regulatory and design support to NV ERP Project activities. RSN is funded by both DP and EM.

- Wackenhut Services, Inc. (WSI) provides security services at the NTS and other Las Vegas facilities. WSI is funded by both DP and EM.

- IT Corporation (IT) provides technical, scientific, and regulatory support for the NV ERP and WMD at the NTS and off-site locations. IT is funded by EM.

Many of the contractors also employ subcontractor organizations. These subcontractors are required to follow the tenets of this plan. 
The National Laboratories and several other organization use the NTS and/or provide support to DOE/NV. These include the Lawrence Livermore National Laboratories (LLNL), Los Alamos National Laboratory (LANL), Sandia National Laboratories (SNL), Desert Research Institute (DRI), U.S. Air Force (USAF), Science Applications International Corporation (SAIC), U.S. Environmental Protection Agency/Environmental Monitoring Systems Laboratory (EPA/EMSL), and Defense Nuclear Agency (DNA). These organizations voluntarily participate in the DOE/NV Wmin/PP Program.

\subsection{Waste Minimization and Pollution Program Organization}

WMin/PP activities are conducted under WMin/PP Program Manager direction and oversight. Support is provided by the DOE/NV WMin/PP Coordinator, who was appointed on May 30, 1990, to coordinate the implementation of WMin/PP for DOE/NV and its contractors. The DOE/NV WMin/PP Coordinator provides guidance and coordination for WMin/PP Awareness Program Activities across all contractor organizations. Each contractor is charged with appointing a waste minimization coordinator for its organization. Most of the NTS users and support organizations have also appointed waste minimization coordinators who participate in DOE/NV WMin/PP activities.

Contractor participation includes serving on the DOE/NV WMin Task Force and the PP Awareness Committee. The WMin Task Force Charter is provided in Appendix D of this Plan. The purpose of the WMin Task Force is to provide DOE/NV with expert input on WMin matters. The input is intended to provide insight based on the Task Force members' collective experience and knowledge. The WMin Task Force reviews and coordinates reporting and training requirements, participates in technology exchange and problem-solving, and provides outreach services to various community organizations. The Pollution Prevention Awareness Committee (PPAC) is a subgroup of the WMin Task Force. The primary focus of the PPAC is employee and community outreach and education. The organization of the WMin Task Force is depicted in Figure 3-1. 


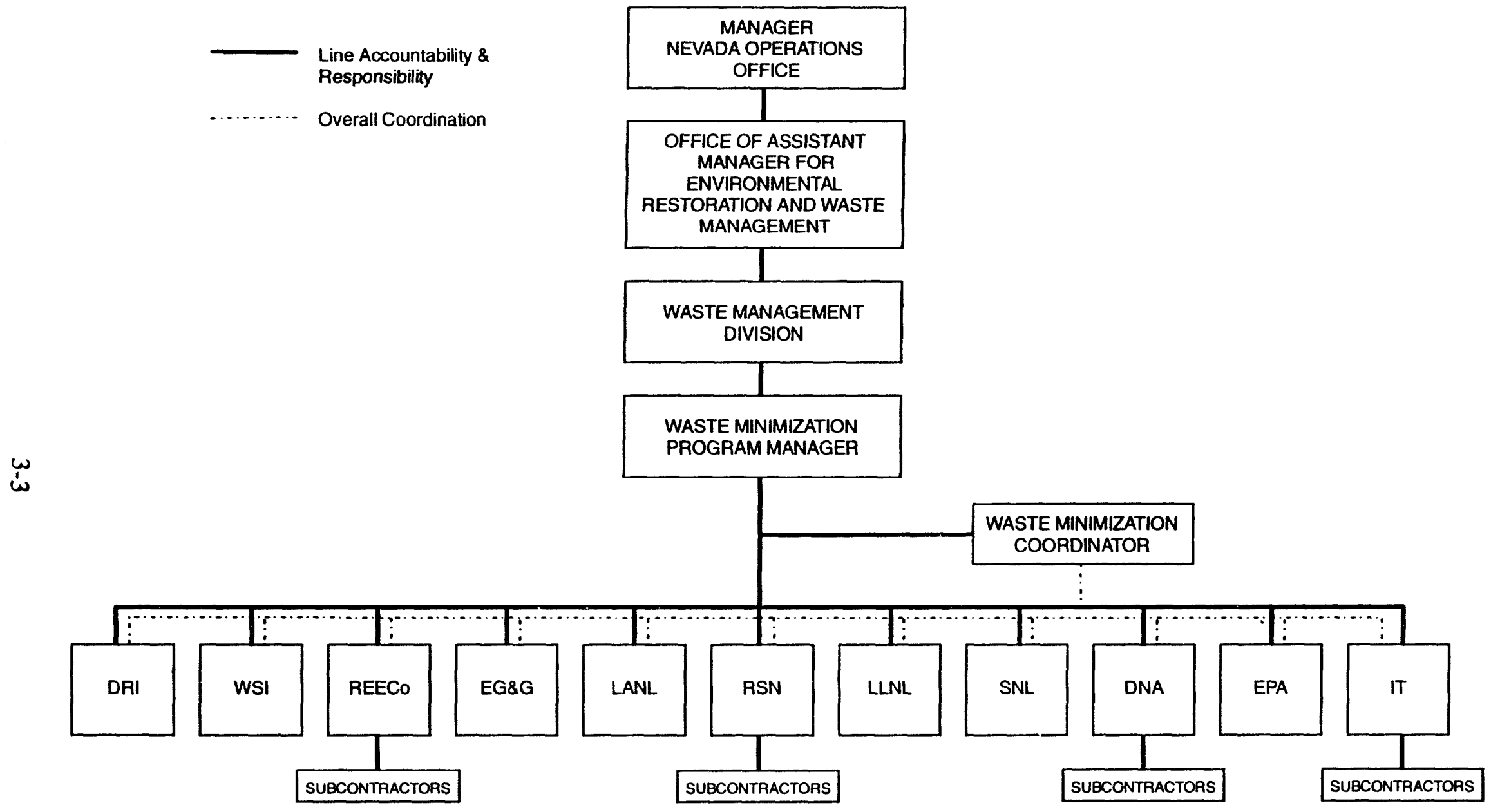

Figure 3-1

Waste Minimization Task Force Organization 


\subsection{Goals}

This WMin/PP Awareness Program Plan establishes three levels of goals

- Program goals for reducing the number of releases and off-site transfers of Emergency Planning and Community Right-to-Know Act (EPCRA), Section 313, toxic chemicals, as specified in Executive Order 12856 and the 1993 WMin/PP Crosscut Plan.

- Site-wide goals for minimization of wastes and pollutants not covered by Executive Order 12856.

- Generator-specific goals for minimization of wastes and pollutants not covered by Executive Order 12856.

DOE/NV has adopted EPCRA and site-wide goals, which are discussed in this section. Generator-specific programs and goals are briefly discussed in Section 8.0. In addition, each generator is required to prepare and submit a generator-specific implementation plan to DOE/NV within 120 days of publication of this plan. These generator-specific implementation plans may include additional goals that are included in the third category.

\subsection{Emergency Planning and Community Right-to-Know Act Goals}

EPCRA goals are specified by Executive Order 12856 and the 1994 WMin/PP Crosscut Plan. These site-wide goals are to reduce the release and off-site transfer of Section 313 toxic chemicals and to achieve a 50-percent reduction Department-wide in these toxic chemicals by December 31, 1999. To the maximum extent practicable, these reductions shall be achieved by implementation of source reduction practices. DOE/NV has adopted these goals in support of the DOE/HQ goal as contained in Executive Order 12856.

The baseline for measuring the 50-percent reduction goal shall be the first year in which toxic chemical releases to the environmental and off-site transfers of such chemicals for treatment and disposal were publicly reported (i.e., 1994). The baseline amount to which the reduction goal pertains shall bo the aggregate amount of toxic chemicals reported in the baseline year for all of the Department's facilities that meet the threshold applicability requirements.

This WMin/PP Awareness Program Plan establishes the approach and the goals for eliminating or reducing the acquisition of products containing extremely hazardous substances 
or toxic chemicals. By August 1995, DOE/NV specifications and standards shall be reviewed to identify opportunities to eliminate or reduce the use of extremely hazardous substances and toxic chemicals, consistent with the safety and reliability requirements of the DOE/NV mission.

\subsection{Other Waste Reduction and Pollution Prevention Goals}

DOE/NV shall also strive to eliminate other wastes that are not covered by Executive Order 12856. Generation of all forms of waste -- sanitary, hazardous, radioactive, and mixed -- will be reviewed to determine where WMin/PP opportunities exist. One method of examining waste generation is through conducting PPOAs in accordance with standards set forth in EPA, EM, and DP guidance. DOE/NV has drafted a PPOA guidance document that provides detailed instructions for conducting PPOAs and tiers down from DOE, Model Pollution Prevention Opportunity Assessment Guidance (Revised December 1993). In addition, WMin/PP is included in all planning documents, such as NV ERP work plans and site characterization plans.

Currently, materials purchased through the REECo Procurement Department are reviewed for health, safety, and waste management implications. If NTS organizations procure their own materials, they are mandated to conduct a similar review prior to product purchase.

Whenever possible, a less-hazardous or nonhazardous substitute product must be found. The DOE/NV Project Manager's approval must be obtained prior to purchasing a product that would present an undue health or safety hazard or produce a hazardous (or mixed) waste. This policy applies to all hazardous materials, including those covered by EPCRA Section 313. Affirmative procurement practices are also in place to encourage the purchase and use of recovered materials. A site-wide recycling program has been established for offsite recycling of paper, aluminum, toner cartridges, and scrap metal. Reusable, recyclable, and saleable materials are identified and managed accordingly rather than discarded as waste.

Types of waste generated by DOE/NV activities fall into two broad categories: remedial and newly-generated wastes. Remedial wastes include legacy wastes, decontamination and decommissioning (D\&D) wastes, weapons dismantlement wastes, and contaminated site cleanup wastes. Newly-generated wastes include secondary wastes (gloves, decontamination rinsate, sampling equipment generated in support of remedial activities) and operations wastes 
(wastes generated as part of normal operations such as waste paint, solvent, motor oil, and office trash). Waste may be further divided into nine categories:

- Radioactive, inciuding low-level waste (LLW), transuranic (TRU), and high-level waste (HLW)

- Hazardous, including Resource Conservation and Recovery Act (RCRA)-regulated, Toxic Substances Control Act (TSCA)- regulated, and state-regulated wastes

- Mixed, including LLW-Mixed (LLW-M), Tru-M, and TSCA-M (as applicable)

- Sanitary

Site-wide quantitative goals for reducing newly-generated operations waste are provided in Table 4-1.

Table 4-1

Site-wide Quantitative Goals for Reduction of Newly Generated Operations Waste

\begin{tabular}{||l|c|c|c||}
\hline \multicolumn{1}{|c|}{ Waste Stream Goals } & \multicolumn{3}{c||}{ Schedule } \\
\hline \multicolumn{1}{|c|}{ Elements } & FY 95 & FY 96 & FY 97 \\
\hline Reduce hazardous waste generation over CY 1994 & $10 \%$ & $10 \%$ & $10 \%$ \\
\hline Reduce nonhazardous waste generation over CY 1994 & $5 \%$ & $5 \%$ & $5 \%$ \\
\hline $\begin{array}{l}\text { Increase recycled commodities over CY 1994 } \\
\text { Reduce procurement of Class I ozone-depleting substances over } \\
\text { CY 1994 }\end{array}$ & $10 \%$ & $10 \%$ & $10 \%$ \\
\hline Reduce Polychlorinated Biphenyl (PCB) amounts over CY 1994 & $5 \%$ & $10 \%$ & $10 \%$ \\
\hline $\begin{array}{l}\text { Comply with EPA's Toxic Chemical Reduction Goals for a 50\% } \\
\text { reduction of designated hazardous chemicals }\end{array}$ & $\begin{array}{l}\text { Progressive through } \\
\text { December 31, 1999* }\end{array}$ \\
\hline
\end{tabular}

"For Fiscal Years 1995 and 1996, the percent of reduction will be compounded and cumulative over previous years starting from baseline 1994.

These goals are reported for nonhazardous, hazardous, and TSCA wastes polychlorinated biphenyls (PCBs). No routine activities generating PCBs or other TSCA materials are 
conducted on or off the NTS. The continuing effort to eliminate or decontaminate all transformers containing PCBs may result in some increases in generation of PCBs; however, it is believed that all PCB-containing transformers have been eliminated or decontaminated. Therefore, the goal listed for PCB reduction is for source elimination rather than waste-stream reduction. Currently, there are no radioactive operations wastes generated; therefore, there are no reduction goals listed. There are no data yet available for NV ERP secondary wastes because most field activities have not yet started. When these field activities are begun, waste generation data will be gathered and reduction goals established. DOE/NV is scheduled to conduct PPOAs of NV ERP activities in an effort to identify mechanisms for reducing newlygenerated secondary wastes.

The number of PPOAs scheduled and planned has not yet been determined. To date, no PPOAs have been conducted in accordance with the most recent standardized guidance, but several were conducted by EG\&G/EM under previously-issued guidance. DOE/NV and contractor personnel attended PPOA training in April 1994 and plan to conduct PPOAs during 1994 and beyond. The WMin Task Force will assist in establishing priority material/waste stream lists (PM/WSL) based on the requirements set forth by DOE/HQ. DOE has established requirements and suggestions for this list as follows:

\section{Required or Mandatory PM/WSL}

- Waste of any amount for which an approved disposal method does not exist (e.g., MW and classified wastes)

- Waste that is equal to 5 percent or more of the facility's total waste stream (total waste $=$ manifest records [hazardous] + radioactive + mixed)

- Clean Air Act Class I Materials (ozone-depleting compounds)

- Known human carcinogens (American Conference of Governmental Industrial Hygienists, Type 1)

- Toxics Reduction Inventory Chemicals - Superfund Amendments and Reauthorization Act, Section 313, Toxic Chemical Solutions

\section{Suggested Additions to PM/WSL}

- Federal, state, and local requirements 
- Permitted waste and materials (e.g., volatile organic compounds and compounds discharged to storm or sanitary sewers)

- Site health risks for hazardous materials and hazardous wastes (e.g., Occupational Safety and Health Administration - suspect carcinogens, teratogens, explosives, PCBs, and asbestos)

- Municipal solid waste

- Materials not categorized as waste inventory

PPOAs will take place using the graded approach. A Level I assessment establishes the site's baseline operational information. Level II PPOAs are used to develop and screen WMin/PP opportunities and recommend viable options for implementation of those opportunities. The objectives of the Level III PPOA is to conduct a detailed analysis of the pr.cess for WMin/PP opportunities and to document the results of the process evaluation in a written report. The WMin Task Force will assist in determining the appropriate level of PPOA to be conducted for a given waste stream and/or process.

\subsection{Programmatic Goals}

Programmatic goals are defined, for purposes of this plan, as activities that support wastereduction activities. An example of a programmatic yoal is to conduct employee awareness training. When employees are aware of WMin/PP concepts, they can apply the concepts at work and help reduce waste. This annual training is required by DOE Order 5400.1 .

Programmatic goals have been established as nine elements: WMin/PP Organization and Infrastructure, Program Development, Employee Involvement, Tracking, Reporting, Technical Assistance, Information and Technology Exchange, Program Evaluation, and Establishment of Reuse and Recycling Goals. The goals associated with each of these areas are provided in Table 4-2. 
Table 4-2

Goals for Each Programmatic Element

\begin{tabular}{|c|c|c|}
\hline Number & Program Element & Goal \\
\hline 1 & $\begin{array}{l}\text { WMin/PP Organization and } \\
\text { Infrastructure }\end{array}$ & $\begin{array}{l}\text { Maintain meeting schedule for WMin/PP Task } \\
\text { Force }\end{array}$ \\
\hline 2 & Program Development & $\begin{array}{l}\text { Create and update site WMin/PP Plans as } \\
\text { required }\end{array}$ \\
\hline 3 & Employee Involvement & Conduct an annual PP Awareness Campaign \\
\hline 4 & Tracking & $\begin{array}{l}\text { Define site-specific requirements for tracking } \\
\text { materials from time of receipt to time of } \\
\text { disposal }\end{array}$ \\
\hline 5 & Reporting & $\begin{array}{l}\text { Fulfill the requirements for all scheduled } \\
\text { WMin/PP reporting }\end{array}$ \\
\hline $6 a$ & $\begin{array}{l}\text { Establish Site-wide Source } \\
\text { Reduction Programs for Hazardous, } \\
\text { Radioactive, and Mixed Waste } \\
\text { Streams }\end{array}$ & Establish a material exchange system \\
\hline $6 b$ & $\begin{array}{l}\text { Establish Site-wide Recycling } \\
\text { Programs for Hazardous, } \\
\text { Radioactive, and Mixed Waste } \\
\text { Streams }\end{array}$ & $\begin{array}{l}\text { Maintain and expand the current recycling } \\
\text { programs }\end{array}$ \\
\hline $6 c$ & $\begin{array}{l}\text { Establish Site-wide Source } \\
\text { Reduction and Recycling Programs } \\
\text { for Sanitary Waste Streams }\end{array}$ & $\begin{array}{l}\text { Establish a method to estimate the quantity of } \\
\text { materials diverted from disposal; maintain the } \\
\text { current program }\end{array}$ \\
\hline 7 & Technical Assistance & Provide PPOA training to site waste generators \\
\hline 8 & $\begin{array}{l}\text { Information and Technology } \\
\text { Exchange }\end{array}$ & Annually attend a DOE-sponsored conference \\
\hline 9 & Program Evaluation & $\begin{array}{l}\text { Establish requirements and conduct an annual } \\
\text { self-assessment }\end{array}$ \\
\hline
\end{tabular}

\subsubsection{Decrement Level Funding}

Estimated funding requirements for each element for Fiscal Year (FY) 1994, 1995, and 1996 are provided below under the decrement-level funding scenario. The tasks to be performed under each element are also described. 


\subsubsection{Waste Minimization and Pollution Program Organization and Infrastructure}

The tasks to be performed under the decrement-level funding scenario are

- Maintain site-wide WMin/PP Coordinator function and staff

- Continue the site WMin Task Force and PPAC and coordinator network activities

- Integrate and monitor the site's waste generation and environmental restoration programs

- Interface with and participate in the DOE/NV and DOE/HQ WMin/PP program

The funding requirements for these activities are

- $\$ 136,800$ in FY 1994

- $\$ 153,800$ in FY 1995

- $\$ 259,000$ in FY 1996

\subsubsection{Program Development}

The tasks to be performed under the decrement-level funding scenario are

- Periodically update WMin/PP site plan and maintain WMin/PP policy statement

- Develop WMin/PP program objectives and establish quantitative goals

- Develop activity schedules for specific tasks and projects

- Formulate budgets for site programmatic activities

- Assign personnel to implement the site WMin/PP program

- Incorporate DOE quality assurance objectives and methods into WMin/PP activities

The funding requirements for these activities are

- $\$ 171,000$ in FY 1994

- $\$ 192,250$ in FY 1995

- $\$ 323,750$ in FY 1996

\subsubsection{Employee Involvement}

The tasks to be performed under the decrement-level funding scenario are

- Update employee general WMin/PP training

- Increase employee WMin/PP awareness

- Include $\mathrm{WMin} / \mathrm{PP}$ as criteria in employee evaluations 
The funding requirements for these activities are

- $\$ 68,400$ in FY 1994

- $\$ 76,900$ in FY 1995

- $\$ 129,500$ in FY 1996

\subsubsection{Tracking}

The tasks to be performed under the decrement-level funding scenario are

- Estimate waste generation, wastes to be removed under the NV ERP, and waste management costs/benefits of WMin/PP.

The funding requirements for this activity are

- $\$ 34,200$ in FY 1994

- $\$ 38,450$ in FY 1995

- $\$ 64,705$ in FY 1996

\subsubsection{Reporting}

The tasks to be performed under the decrement-level funding scenario are

- Fulfill all WMin/PP-driven compliance reporting requirements

- Complete all WMin/PP Headquarters and DOE/NV reporting requirements

The funding requirements for these activities are

- $\$ 68,400$ in FY 1994

- $\$ 76,900$ in FY 1995

- $\$ 129,500$ in FY 1996

\subsubsection{Establish Site-wide Source Reduction and Recycling Programs}

The tasks to be performed under the decrement-level funding scenario are

- Reduce the use and release of toxic chemicals

- Use affirmative procurement practices to encourage the purchase and use of recovered materials 
The funding requirements for these activities are

- $\$ 68,400$ in FY 1994

- $\$ 76,900$ in FY 1995

- $\$ 129.500$ in FY 1996

\subsubsection{Technical Assistance}

The tasks to be performed under the decrement-level funding scenario are

- Assist generators and NV ERP program managers in setting quantitative and qualitative goals

- Assist generators in assessing and implementing opportunities

The funding requirements for these activities are

- $\$ 34,200$ in FY 1994

- $\$ 38,450$ in FY 1995

- $\$ 64,750$ in FY 1996

\subsubsection{Information and Technology Exchange}

The tasks to be performed under the decrement-level funding scenario are

- Participate in seminars, workshops, and meetings

- Periodically conduct meetings with generator WMin/PP coordinators

The funding requirements for these activities are

- $\$ 68.400$ in FY 1994

- $\$ 76,900$ in FY 1995

- $\$ 129,500$ in FY 1996

\subsubsection{Program Evaluation}

The tasks to be performed under the decrement-level funding scenario are

- Assess program implementation status

- Evaluate program performance against goals

The funding requirements for these activities are

- $\$ 34,200$ in FY 1994

- $\$ 38,450$ in FY 1995

- $\$ 64,750$ in FY 1996 


\subsubsection{Target- and Planning-Level Funding}

Estimated funding requirements for each element for FY 1996, 1997, 1998, and 1999 are provided below under the target- and planning-level funding scenaris. The DOE/NV ADS indicates that the target and planning levels are equal during FY 1996; planning-level funding requirements are reported after target-level funding levels below. The tasks to be performed under each element are described; elements that are included under the target and planning level ('but not under the decrement level) are underlined. In some cases, no tasks above decrement level are added. In these cases, the same tasks will be accomplished with a higher level of effort. For example, more coordination meetings may be conducted and conferences attended under target and planning level funding scenarios. In other cases, tasks are identified as both target and planning level tasks. Again, increased funding will bring about a higher level of effort.

\subsubsection{Waste Minimization and Pollution Program Organization and Infrastructure}

The tasks to be performed under the target- and planning-level funding scenarios are

- Maintain site-wide WMin/PP Coordinator function and staff

- Continue the site WMin Task Force and PPAC and coordinator network activities

- Integrate and monitor the site's waste generation and environmental restoration programs

- Interface with and participate in the DOE/NV and DOE/HQ WMin/PP program

The funding requirements for these activities are

- $\$ 329,000$ in FY 1996

- $\$ 337,600$ in FY 1997 (target), $\$ 379,000$ in FY 1997 (planning)

- $\$ 347,800$ in FY 1998 (target), $\$ 390,400$ in FY 1998 (planning)

- $\$ 365,200$ in FY 1999 (target), \$402,000 in FY 1999 (planning)

\subsubsection{Program Development}

The tasks to be performed under the target- and planning-level funding scenarios, are

- Periodically update WMin/PP site plan

- Maintain WMin/PP policy statement

- Develop WMin/PP program objectives and establish quantitative goals

- Develop activity schedules for specific tasks and projects

- Formulate budgets for site programmatic activities

- Assign personnel to implement the site WMin/PP program 
- Incorporate DOE quality assurance objectives and methods into WMin/PP activities

- Assist with integration of WMin/PP practices into contractor operating procedures (target)

- Estimate waste management costs for use in decision making (target)

- Promote regulatory review and reform (planning)

- Update DOE policies, Orders, and procedures to integrate WMin/PP (planning)

The funding requirements for these activities are

- $\$ 411,250$ in FY 1996

- $\$ 422,000$ in FY 1997 (target), \$473,750 in FY 1997 (planning)

- $\$ 434,750$ in FY 1998 (target), \$488,000 in FY 1998 (planning)

- \$456,500 in FY 1999 (target), \$502,500 in FY 1999 (planning)

\subsubsection{Employee Involvement}

The tasks to be performed under the target and planning level funding scenarios are

- Update employee general WMin/PP training

- Increase employee WMin/PP awareness

- Include WMin/PP as criteria in employee evaluations

- Award and recognize employees for WMin/PP efforts (target and planning)

- Publicize WMin/PP progress in newsletters or other site publications (target and planning)

- Conduct additional employee training (planning)

The funding requirements for these activities are

- $\$ 164,500$ in FY 1996

- $\$ 168,800$ in FY 1997 (target), \$189,500 in FY 1997 (planning)

- $\$ 173,900$ in FY 1998 (target), \$195,200 in FY 1998 (planning)

- $\$ 182,600$ in FY 1999 (target), \$201,000 in FY 1999 (planning)

\subsubsection{Tracking}

The tasks to be performed under the target- and planning-level funding scenarios are

- Estimate waste generation, wastes to be removed under the environmental restoration project, and waste management costs/benefits of WMin/PP

- Enhance site material inventory tracking for WMin/PP, urposes (target and planning)

- Enhance site waste tracking for WMin/PP purposes (target and planning)

- Standardize material and waste tracking systems (planning) 
The funding requirements for these activities are

- $\$ 82,250$ in FY 1996

- $\$ 84,400$ in FY 1997 (target), \$94,750 in FY 1997 (planning)

- $\$ 86,950$ in FY 1998 (target), \$97,600 in FY 1998 (planning)

- \$91,300 in FY 1999 (target), \$100,500 in FY 1999 (planning)

\subsubsection{Reporting}

The tasks to be performed under the target- and planning-level funding scenarios are

- Fulfill all WMin/PP driven compliance reporting requirements

- Complete all WMin/PP Headquarters and DOE/NV reporting requirements

- Determine and report waste generation baseline (target and planning)

- Report removal of wastes from NV ERP activities (target)

The funding requirements for these activities are

- $\$ 164,500$ in FY 1996

- $\$ 168,800$ in FY 1997 (target), $\$ 189,500$ in FY 1997 (planning)

- $\$ 173,900$ in FY 1998 (target), \$195,200 in FY 1998 (planning)

- $\$ 182,600$ in FY 1999 (target), \$201,000 in FY 1999 (planning)

\subsubsection{Establish Site-wide Source Reduction and Recycling Programs}

The tasks to be performed under the target- and planning-level funding scenarios are

- Reduce the use and release of toxic chemicals

- Use affirmative procurement practices to encourage the purchase and use of recovered materials

- Substitute toxic chemicals and other materials (target and planning)

- Exchange excess toxic chemicals and hazardous materials so that they do not become waste (target and planning)

- Reuse or recycle hazardous and radioactive wastes on site and recycle hazardous wastes off site (target and planning)

- Recycle or reuse sanitary wastes (target and planning)

- Perform PPOAs and identify WMin/PP projects (target)

- Implement WMin/PP projects identified through PPOAs (planning) 
The funding requirements for these activities are

- $\$ 164,500$ in FY 1996

- $\$ 168,800$ in FY 1997 (target), \$189,500 in FY 1997 (planning)

- $\$ 173,900$ in FY 1998 (target), $\$ 195,200$ in FY 1998 (planning)

- $\$ 182,600$ in FY 1999 (target), $\$ 201,000$ in FY 1999 (planning)

\subsubsection{Technical Assistance}

The tasks to be performed under the target- and planning-level funding scenarios are

- Assist generators and NV ERP managers in setting quantitative and qualitative goals

- Assist generators in assessing and implementing opportunities

- Assist generators in determining waste-generation baseline (target and planning)

- Assist generators and NV ERP in establishing model WMin/PP programs (planning)

- Incorporate design of WMin/PP into new products, processes, and facilities (planning)

The funding requirements for these activities are

- $\$ 82,250$ in FY 1996

- $\$ 84,400$ in FY 1997 (target), $\$ 94,750$ in FY 1997 (planning)

- $\$ 86,950$ in FY 1998 (target), $\$ 97,600$ in FY 1998 (planning)

- $\$ 91,300$ in FY 1999 (target), \$100,500 in FY 1999 (planning)

\subsubsection{Information and Technology Exchange}

The tasks to be performed under the target- and planning-level funding scenarios are

- Participate in seminars, workshops, and meetings

- Periodically conduct meetings with generator WMin/PP coordinators

- Participate in WMin/PP information clearinghouse (target)

- Foster outreach and participate in public relations (target and planning)

The funding requirements for these activities are

- $\$ 164,500$ in FY 1996

- $\quad \$ 168,800$ in FY 1997 (target), $\$ 189,500$ in FY 1997 (planning)

- $\quad \$ 173,900$ in FY 1998 (target), \$195,200 in FY 1998 (planning)

- $\$ 182,600$ in FY 1999 (target), \$201,000 in FY 1999 (planning) 


\subsubsection{Program Evaluation}

The tasks to be performed under the target- and planning-level funding scenarios are

- Assess program implementation status

- Evaluate program performance against goals

- Assess employee participation (target and planning)

- Evaluate designs for incorporation of WMin/PP into new products, processes, and facilities (planning)

The funding requirements for these activities are

- $\$ 82,250$ in FY 1996

- $\$ 84,400$ in FY 1997 (target), $\$ 94,750$ in FY 1997 (planning)

- $\$ 86,950$ in FY 1998 (target), $\$ 97,600$ in FY 1998 (planning)

- $\$ 91,300$ in FY 1999 (target), \$100,500 in FY 1999 (planning) 


\subsection{Waste Minimization and Pollution Program Status, Activities, and Resource Requirements}

Key site-wide programmatic activities and elements in support of achieving the goals established in Section 4.0 of this Plan, the Environment, Safety, and Health Management Plan, and the $1993 \mathrm{WMin} / \mathrm{PP}$ Crosscut Plan are discussed below. These key activities and elements were provided in guidance supplied by DOE/HQ and are summarized in Section 5.1. Many of these elements are already in place for DOE/NV activities; therefore, the current status and accomplishments to date are discussed in Section 5.2. Section 5.3 provides a brief overview of additional planned activities, and Section 5.4 discusses assumptions and consequences. Generator-specific activities are discussed in Section 8.0 of this Plan and in the generatorspecific implementation plans.

Budget estimates for WMin/PP activities are provided in Appendix B of this Plan. This section provides a summary of key activities and elements under each Cognizant Secretarial Officer for FY 1994, 1995, and 1996. Note that the EM budget estimates encompass funding requirements for DOE/NV and across all EM-funded contractor organizations.

\subsection{Key Elements and Current Status}

The activities for each of the nine program elements and the current status of each are provided below.

\subsubsection{Organization and Infrastructure}

The key activities included in WMin/PP Organization and Infrastructure are

- Designate a Site WMin/PP Coordinator

- Establish the Site WMin/PP Committee, including the WMin/PP Coordinator Network

- Integrate and monitor the Site's Generator and Environmental Restoration Programs

- Interface with and participate in the DOE/NV and DOE/HQ WMin/PP Program

The elements for WMin/PP Organization and Infrastructure have been addressed through appointment of the DOE/NV WMin/PP Coordinator, establishment of the WMin Task Force and PP Awareness Committee, and development of this Plan and the generator-specific implementation plans. 
The DOE/NV WMin/PP Coordinator participates in the WMin/PP Coordinator Network by attending quarterly meetings with other sites' Coordinators. The DOE/NV WMin/PP Coordinator also participates in the WMin Contractors' Coordination Group and the monthly conference calls with DOE/HQ EM-352. The DOE/NV WMin/PP Coordinator chairs the WMin Task Force meetings, which are held six times per year. Through quarterly reporting requirements, the NV WMin/PP Coordinator and Program Manager monitor the generator and NV ERP WMin/PP programs. WMin Task Force members frequently attend and present papers at workshops and conferences sponsored by DOE/HQ.

\subsubsection{Program Development}

The key elements of program development are

- Develop and periodically update the WMin/PP Site Plan

- Develop Site WMin/PP Policy statement

- Develop WMin/PP Program objectives and establish quantitative and qualitative goals

- Develop activity schedules for specific tasks and projects

- Formulate budgets for site programmatic activities

- Assign personnel to develop and implement the Site WMin/PP Program

- Integrate $\mathrm{WMin} / \mathrm{PP}$ practices into site operating procedures

- Incorporate DOE quality assurance methods and objectives into WMin/PP activities

The NV WMin/PP Awareness Program Plan was initially published in June 1991. The DOE Nevada Field Office Assistant Manager for Environmental Restoration and Waste Management Quality Assurance Program Description (April 1993) was adopted into the DOE/NV WMin/PP Awareness Program Plan by reference. The WMin/PP Awareness Program Plan includes quantitative and qualitative goals, schedules, a policy statement, and an update schedule. This Plan is a periodic site-plan update. Generator upper-management staff is also asked to prepare and sign a WMin/PP policy statement that is to be issued to all employees and made a part of the generator-specific WMin/PP implementation plan. Generators are also charged with developing procedures that integrate WMin/PP practices. Under the direction of the DOE/NV Program Manager, the DOE/NV WMin/PP Coordinator formulates budgets for site programmatic activities. The DOE/NV WMin/PP Coordinator is responsible to the DOE/NV Program Manager for development and implementation of sitewide programmatic activities covered by this plan. In addition, each generator WMin/PP Coordinator is charged with developing and implementing the requirements of this plan and their generator-specific implementation plan. 


\subsubsection{Employee Involvement}

The key elements for employee involvement are

- Develop and update employee general WMin/PP training

- Increase employee WMin/PP awareness

- Award and recognize employees for WMin/PP efforts

- Include WMin/PP as criteria in employee evaluation

- Publicize WMin/PP progress in newsletters or other site publications

Employee involvement is one of the strongest aspects of the DOE/NV WMin/PP Program. General awareness training was developed during FY 1993 by the WMin Task Force and made available to all DOE/NV contractors and NTS users. The training package is available both in hard-copy format and on diskette. These formats enable individual generators to customize the training by including generator-specific information and goals, company logos, and personnel information. The training program is periodically reviewed by the WMin/PP Task Force to ensure that it is up-to-date and accurate and to determine where improvements can be made.

To increase employee WMin/PP awareness, WMin/PP information is published periodically in the NTS News and Views, an employee newsletter, and included in paycheck stuffers. Some of the DOE/NV contractors also have internal newsletters that publish WMin/PP news, and articles about DOE/NV WMin/PP activities have been published in newsletters published by DOE/HQ. Recycling bins are clearly labeled and placed in various locations around the NTS and Las Vegas facilities. Employees are invited to participate in a WMin/PP suggestion program. By submitting a suggestion, employees are given an award. During FY 1992 through 1994, employees were provided with a polo shirt with the PP Awareness Committee's Logo ("Pollution is NO Solution" over a colored globe). Thus, employees became essentially walking billboards for the program. Most DOE/NV contractors and users also provide monetary awards for outstanding WMin/PP suggestions through their existing employee suggestion programs. A contractor employee is appointed chair of the PP Awareness Committee each year. After serving one year, the chairperson is presented with a plaque recognizing his or her efforts. In addition, many of the DOE/NV contractors include WMin/PP criteria in employee evaluations. 


\subsubsection{Tracking}

The key elements of tracking are

- Establish or enhance site material inventory tracking for WMin/PP purposes

- Establish or enhance site waste tracking for WMin/PP purposes

- Estimate waste generation, wastes to be removed under the NV ERP, and waste management costs/benefits of $\mathrm{Wmin} / \mathrm{PP}$

Generators are responsible for tracking their waste. To enhance tracking programs, the WMin Task Force developed a standardized tracking and reporting format that closely follows the reporting format required by the Annual Report on Waste Generation and Waste Minimization Progress. Quarterly reports are delivered to the DOE/NV WMin/PP Coordinator. By tracking waste on a quarterly basis, trends can be spotted early and annual reporting is less burdensome. Currently, EG\&G/EM is leading a task force for integration of FlowGemini ${ }^{\circledR}$, a computer-based tracking system, across all DOE/NV contractors. FlowGemini ${ }^{\circledR}$ will allow for cradle-to-grave tracking of hazardous materials and waste through the implementation and management of a computerized database.

Materials are tracked in accordance with NTS-SOP-5409, Hazardous Materials and Waste Management. NTS-SOP-5409 establishes a review committee to examine Material Safety Data Sheets (MSDSs) for employee health and safety and waste management considerations. The MSDS is reviewed prior to purchase of the product.

Mixed waste generation is estimated at least annually as part of the inventory required by the Federal Facilities Compliance Act (FFCA). In addition, a semiannual data call is completed for all waste types for the Programmatic Environmental Impact Statement (PEIS). Through these data calls and updates, estimates are kept current for both ongoing operations and Environmental Restoration Projects. Cost/benefit analyses of recycling versus disposal have been completed by REECo and EG\&G/EM. Cost/benefit analyses of in situ treatment versus removal will provide rationale for selection of remedial options for Environmental Restoration Projects. PPOAs will be conducted to enhance tracking of materials and wastes. 


\subsubsection{Reporting}

The key elements for reporting are

- Determine and report waste generation baseline

- Fulfill all WMin/PP-driven compliance reporting requirements

- Report removal of wastes from NV ERP activities

- Complete all WMin/PP DOE/HQ and DOE/NV reporting requirements

The primary reporting requirement is the Annual Report on Waste Generation and Waste Minimization Progress, as required by DOE Order 5400.1. Each contractor currently participates in the annual report. As mentioned in Section 5.1.4, contractors also complete a quarterly report that is provided to the DOE/NV WMin/PP Coordinator. Related reporting requirements are the FFCA and PEIS waste data calls to which all involved contractors respond. NV ERP removal activities have been limited to date, but are reported by the NV ERP contractor.

\subsubsection{Site-wide Reduction Programs}

The key elements in establishing site-wide source reduction and recycling programs for hazardous, radioactive, mixed, and sanitary waste streams are

- Reduce the use and release of toxic chemicals

- Substitute toxic chemicals and other hazardous materials

- Exchange excess toxic chemicals and hazardous materials so that they do not become wastes

- Reuse or recycle hazardous, radioactive, and sanitary wastes on site

- Recycle hazardous and sanitary wastes off site

- Use affirmative procurement practices to encourage the purchase and use of recovered materials

- Reuse or sell sanitary wastes (such as scrap metal)

All DOE/NV contractors have paper recycling programs in place or take advantage of the NTS-wide recycling program. The NTS-wide recycling program for solid waste includes paper, aluminum cans, and cardboard. These wastes are currently being recycled through a 
subcontractor. Toner cartridges are also recycled, resulting in significant cost savings and waste reduction. Solvents, paint thinners, and lacquer thinner are recycled at the NTS. Salvaged items are sold at public auctions when sufficient quantities are accumulated. Salvaged items sold to date include vehicles, electric cable, light and heavy iron, aluminum. brass and copper, tires, precious metals, and lead. Photochemicals are also recycled, and silver is recovered from photo laboratory operations. Water from steam-cleaning operations is cleaned through recycling equipment and is reused.

Antifreeze is not changed out in NTS Fleet Operations. Instead, it is augmented with an additive that extends its effectiveness as long as it is used. Dye tool coolant in equipment such as lathes is recycled via a portable recycling machine. Freons are also recycled on site to comply with EPA's Clean Air Act, Sections 608 and 609. Employees are trained and certified to meet regulatory requirements. Lead acid batteries are recycled through a subcontract as of FY 1992. Used oil is also recycled offsite.

Material substitution, good op'ration practices, and process-equipment modification-reduction methods are all used in the DOE/NV WMin Program.

\subsubsection{Technical Assistance}

The key elements and activities involving technical assistance are

- Assist generators and NV ERP managers in setting quantitative and qualitative goals

- Assist generators in determining waste generation baseline

- Assist generators in assessing and implementing opportunities

- Assist generators and NV ERP managers in establishing model WMin/PP programs

Technical assistance is provided by the DOE/NV Program Manager, DOE/NV WMin/PP Coordinator, and the WMin Task Force. Task Force meetings serve as a forum for information and technology exchange. Lessons learned, new product information, and guidance from EPA and DOE/HQ are shared at Task Force meetings. Guidance is also provided in setting goals, determining waste-generation baselines, assessing and implementing opportunities, and establishing model programs. DOE/NV has been selected as a potential model site for application of PPOAs to NV ERP activities. NV ERP staff have been encouraged to participate in WMin/PP activities, including the WMin Task Force, PP Awareness Committee, and workshops and meetings sponsored by DOE/HQ. 


\subsubsection{Information and Technology Exchange}

The key elements and activities for information and technology exchange are

- Participate in seminars, workshops, and meetings

- Periodically hold meetings with generator WMin/PP Coordinators

- Participate in the WMin/PP clearinghouse

- Foster outreach and participate in public relations

Information and technology exchange is accomplished through attendance at DOE/HQsponsored meetings, workshops, and conferences. There are six annual WMin Task Force meetings per year, and twelve PPAC meetings per year. The WMin Task Force and WMin/PP Coordinator's office act as an information clearinghouses for all NV contractors and users. Activities adopted by the PPAC foster outreach and provide positive public relations for the DOE/NV WMin/PP program. In addition, WMin Task Force and PPAC members participate in many activities on their own time (such as teaching at the Community College and providing expert advise to small businesses), which further enhance DOE/NV image and accomplish public outreach.

\subsubsection{Program Evaluation}

The key elements and activities for program evaluation are

- Assess employee participation

- Assess program implementation status

- Evaluate program performance against goals

Currently, the DOE/NV Program Manager and DOE/NV WMin/PP Coordinator conduct periodic assessments of all generators. Program performance is evaluated through these periodic assessments and through the Cost-Plus-Award-Fee (CPAF) grading program. Through the awards program and quarterly reports, employee participation is monitored and assessed. The PP Awareness Committee is tasked with employee awareness and outreach. The monthly Committee meetings provide a forum for discussion of methods to enhance employee awareness and provide generators the opportunity to conduct self-assessment of employee participation. 


\subsection{Planned Activities}

During FY 1995 and 1996, the following activities are planned for waste minimization oversight (DP) and coordination (EM). Activities are funded by EM unless otherwise noted.

\subsubsection{Organization and Infrastructure}

- Six WMin Task Force meetings will be conducted each year.

- Twelve PPAC meetings will be conducted each year.

- At least one DOE-sponsored PP conference will be attended each year.

- The DOE/NV WMin/PP Coordinator function will continue.

\subsubsection{Program Development}

- Generator-specific WMin/PP Plans will be created and/or updated as required.

- The Site WMin/PP Plan will be updated, as required.

\subsubsection{Employee Involvement}

- The requirement for scheduled WMin/PP reporting and training will be fulfilled.

- PPOA training will be provided to site waste generators.

- WMin/PP awareness training will be conducted (DP and EM).

- Awareness programs and campaigns will be presented, and goals and success criteria will be better defined.

\subsubsection{Tracking}

- The Material and Waste Tracking System will be standardized (DP and EM under target and planning-level funding scenarios).

\subsubsection{Reporting}

- DOE/NV will participate in the $33 / 50$ program (DP).

- Quarterly reports will be provided to the WMin/PP Coordinator (DP and EM). 
- Disposal data for priority and EPCRA 313 chemicals will be provided (DP).

- The DOE/NV WMin/PP Coordinator will roll up contractor waste reduction reports, as required.

\subsubsection{Source Reduction and Recycling Programs}

- PPOAs will be conducted.

- Goals will be established and/or revised to minimize waste generation and reduce environmental and toxic chemical releases.

- New equipment for recycling photochemicals, silver recovery, and $\mathrm{pH}$ pretreatment will be installed. This will reduce photo fixer consumption by 50 percent (DP).

\subsubsection{Technical Assistance}

- Affirmative procurement will be conducted (DP and EM).

\subsubsection{Information and Technology Exchange}

- The annual Quality Improvement Conference will be attended.

- WMin/PP Technology Transfer and Information Exchange will be facilitated.

- A WMin/PP Outreach and Public Relations Program will be developed.

\subsubsection{Program Evaluation}

- Implementation of the contractors' WMin/PP plans will be verified (DP and EM).

- The contractor Annual Waste Reduction Report will be prepared (DP and EM).

- Inspections, surveillances, and audits will be conducted to verify implementation of WMin/PP plans and incorporation of WMin/PP into design criteria (DP).

\subsection{Outyear Activities}

Planned outyear activities include maintaining the program at its current level, continuing reduction of waste (particularly priority and Section 313 chemicals), conducting additional PPOAs, and updating the WMin/PP Awareness Flan and Generator-Specific Implementation Plans, as required. 


\subsection{Assumptions and Consequences}

Assumptions are as follows:

- The weapons-related activities will not increase in future years; however, NV ERP activities will increase.

- DOE/WMD will receive full presidential budget funding for FY 1995; target-level funding will be provided by both DP and EM.

- Regulatory requirements will be enforced, requiring continued emphasis on compliance.

- The Department will increase its investment in long-term environmental strategies, even while it is faced with increasing short-term waste-management budget demands.

- The costs of waste management and environmental compliance will increase as waste treatment and disposal capacity decreases.

- Funding for WMin/PP will have a higher priority and will be sufficient to meet the goals established in this plan.

- DOE will work in cooperation with regulators and the public to solve waste management problems and operate its facilities in an environmentally sound manner.

- Regulatory requirements for WMin/PP will continue to increase, and DOE will continue to place an increased emphasis on WMin/PP.

Consequences are as follows:

- Any major funding reductions would result in an inoperable waste minimization program.

- Failure to fund the program at the Target/Planning level (per ADS) would result in the Generator Site Implementation Programs, the Incentive Aggressive Program, Public Outreach Aggressive Program, and the DOE-wide Success documentation not being implemented. 


\subsection{Site-wide Analysis}

The majority of WMin/PP activities are funded by EM; however, several contractors and DOE/NV obtain funding from both DP and EM. The DOE/NV WMin/PP Coordinator is responsible for reviewing both DP and EM ADSs to determine whether funding overlaps exist or if any activities have been overlooked. In addition, the DOE/NV WMin/PP Coordinator is responsible for coordination of the individual contractor EM ADSs, which are rolled up into one ADS. The exception is the funding for NV ERP WMin/PP activities that are incorporated into the individual subproject ADSs. The activities are coordinated, however, through the WMin/PP Task Force. The gencrators are responsible for preparing WMin/PP Implementation Plans that address implementation of the requirements of this plan, relevant regulations, and DOE Orders and policies. These Implementation Plans are reviewed by the WMin/PP Program Manager and Coordinator to ensure that activities are not overlooked and that programs do not overlap unnecessarily. Through the WMin/PP Task Force, ideas are shared and communication is facilitated to help ensure that a problem is solved only once.

The largest roadblock to accomplishing the goals set forth in the WMin/PP Awareness Plan is inadequate funding. If adequate funds are not provided, contractors are not able to participate in or contribute to WMin/PP activities. 


\subsection{Program Status}

DOE/NV currently has an ongoing WMin/PP Program that has received national recognition for excellence. DOE/NV has a strong management and worker commitment to WMin/PP. WMin/PP activities are conducted under WMin/PP Program Manager direction and oversight. Support is provided by the DOE/NV WMin/PP Coordinator. The DOE/NV WMin/PP Coordinator provides guidance and coordination for WMin/PP Awareness Program Activities across all contractor organizations. Each contractor is charged with appointing a waste minimization coordinator for their organization.

Activities conducted to date include establishment of paper, cardboard, aluminum can, motor oil, antifreeze, and chlorofluorocarbon (CFC) recycling and/or recovery programs.

A 60-percent reduction in the use of hazardous solvents was achieved through product substitution. Participation in the paper recycling program has risen 100 percent from 1989. Community outreach activities included procuring a $\$ 30,000$ grant for an environmental education nature preserve that will serve students in the Las Vegas metropolitan area, participating in school programs, and providing a booth at the annual Expanding Your Horizons conference. Numerous DOE/NV and contractor employees have participated in WMin/PP conferences as attendees and speakers. Surveillances have been conducted to help ensure that contractors are implementing their WMin/PP program plans.

All NTS contractors and users participate in a WMin Task Force, which ensures coordination of activities, information sharing, and technology transfer. Through the Task Force, the program is coordinated and communication enhanced among the various contractors. This helps ensure that no problem is solved more than once.

The WMin Task Force was recognized with the national DOE 1994 Pollution Prevention Award for Outstanding Local Achievement for activities associated with the Whitney Mesa Environmental Education Nature Preserve. The DOE/NV WMin Task Force also received recognition for its team spirit and commitment to WMin/PP. 


\subsection{Generator-Specific Programs and Plans}

As discussed in Section 3.2, there are five primary DOE/NV support contractors: REECo, EG\&G/EM, RSN, WSI, and IT. An overview of each contractor's program is provided below. Because the support organizations, such as DRI and SAIC, are funded separately, their programs and plans are beyond the scope of this plan. . Each generator is required to address eight implementation program elements:

- Organization and infrastructure

- Site/Facility program development

- Site-wide program participation

- Site/Facility training

- Opportunity assessments

- Implement source reduction and recycling opportunities

- Design considerations

- Program evaluation

Each of the five primary support contractors has developed a generator-specific WMin/PP Implementation Plan, which is submitted to DOE/NV for review and concurrence. The generator-specific WMin/PP Implementation Plans are required to address each of the eight elements. A synopsis of each primary support contractor's program is described below, along with a summary of planned activities for FY 1994 through 1999.

\subsection{Reynolds Electrical \& Engineering Co., Inc.}

REECo is the prime Management and Operating (M\&O) Contractor for the NTS. As discussed in Section 3.2 of this Plan, REECo is responsible for construction support, drilling, mining, feeding, housing, purchasing, waste management, medical services, fire protection, transportation, radiation monitoring, engineering services, and warehousing at the NTS. REECo manages the site-wide recycling and salvage programs.

\subsubsection{Current Status}

REECo has appointed a WMin/PP Coordinator, who is responsible for updating and overseeing implementation of the generator-specific WMin/PP Implementation Plan. The REECo WMin/PP Coordinator and several Environmental Compliance Coordinators have attended PPOA training; additional REECo employees are scheduled to obtain the training during the remainder of FY 1994 and beyond. REECo will participate in most, and lead in 
some, PPOAs at the NTS. REECo has implemented source reduction and recycling opportunities for hazardous and sanitary waste streams and is exploring opportunities to reduce/recycle mixed and radioactive waste streams. WMin/PP principles and technologies are integrated into designs prepared and/or approved by REECo. The REECo WMin/PP Coordinator conducts periodic self-assessments to evaluate program implementation status and the effect of source reduction and recycling on waste generation and disposal rates. REECo has conducted cost/benefit analyses on recycling versus landfilling.

\subsubsection{Future Plans}

Future plans include maintaining current recycling, salvage, and reuse programs; continued implementation of source reduction; and continued participation in WMin Task Force activities. Additional plans include conducting PPOAs, continuing waste baselining efforts, and conducting cost/benefit and pay-back calculations for additional waste streams. Employee incentive and training programs will continue, and REECo personnel will continue to participate in community outreach activities. REECo will also provide disposal data for the 17 priority chemicals; EPCRA Section 313 chemicals; and Form R, Part II chemicals.

\subsection{EG\&G Energy Measurements, Inc.}

EG\&G EM is one of six elements of EG\&G, Inc.'s DOE Support Group that supports energy programs and nuclear weapons development and testing. These six elements of EG\&G account for more than half of the corporation's employees.

EG\&G/EM has offices at Goleta, Pleasanton, and Santa Barbara, California; Las Vegas, Nevada; Los Alamos, New Mexico; and Andrews Air Force Base near Washington, D.C. and Kirtland Air Force Base. In addition, a number of environmental research scientists are stationed at the Naval Petroleum Reserves near Bakersfield, California, and at Camp Roberts in Paso Robles, California. All of these offices are administratively managed from the Las Vegas office.

Employees at the Las Vegas Area Operations (LVAO) work on a variety of scientific and technical projects. Most of the projects involve developing complex instruments that measure the energy produced by nuclear devices during DOE's underground tests. Teams of scientusts, engineers, and technicians work closely to design, assemble, and field sophisticated electronic and electro-optic components that are able to record signals lasting only a few billionths of a 
second. More than half of EG\&G/EM's employees are currently employed at the LVAO. The LVAO includes facilities in North Las Vegas, the Nevada Test Site, and Nellis Air Force Base. Nellis houses the Remote Sensing Laboratory which conducts aerial radiation and environmental surveys for government and commercial nuclear power sites to measure the levels of background radiation around those sites. The laboratory is also an essential part of the United States' ability to respond to a wide range of nuclear emergencies. If an emergency involving radiation were to occur, laboratory employees would be an essential part of the DOE team that would respond.

As a prime contractor to DOE, EG\&G/EM employs more than 1,500 people at its 7 locations.

\subsubsection{Current Status}

The EG\&G/EM WMin/PP Awareness Implementation Plan was formally established in December 1991. EG\&G/EM is updating this plan again to meet current standards and requirements set forth by DOE/HQ, EPA, and Executive Order 12856. The Plan will also address the requirements of DOE Order 5400.1 and the DOE Waste Reduction Policy Statement for DOE Order 5400.1, RCRA, Pollution Prevention Act of 1990, and Executive Order 12843. The EG\&G/EM Plan will apply to all NTS and off-NTS operations. The Plan will be updated annually, as required. Program performance will be assessed through schedule management, quality assurance, and functional reviews. Procedures have been developed and policy statements issued regarding WMin/PP expectations and requirements. Management and supervision are expected to be familiar with procedures and ensure compliance during operational activities. Individuals with direct responsibility regarding waste minimization are graded on those activities at least annually during their performance appraisal.

EG\&G/EM is in the process of identifying hazardous and nonhazardous waste streams at each location. A site-specific Process/Waste Review List was distributed to each location for validation. The list addresses the waste streams, type of air emissions, waste water, hazardous waste and its EPA or state waste code, and solid waste. The processes will be ranked according to health and safety and regulatory requirements. 
DOE/NV has initiated PPOA training; EG\&G/EM staff have attended this training. EG\&G/EM will initiate the PPOA training for all NV contractors. EG\&G/EM performed two PPOAs in FY 1993 and plan to perform ten in FY 1994. PPOAs conducted in FY 1994 will follow the guidance provided by Kansas City.

Waste minimization suggestions resulting in cost savings or reduced pollution are eligible for monetary awards under the EG\&G/EM Employee Suggestion Awards Program. This incentive has been emphasized in Standard Operating Procedures. Employees receive a DOE/NV Pollution Prevention polo shirt for credible WMin/PP suggestions.

The EG\&G WMin/PP Coordinator participates in WMin Task Force and PPOA meetings and activities. The Coordinator participates in community outreach programs, such as the Whitney Mesa Environmental Education Nature Preserve, Expanding Your Horizons Conference, and Earth Day. Other EG\&G/EM employees are also encouraged to participate in community outreach activities that enhance DOE/NV's image and promote the precepts of WMin/PP.

LVAO has established a recycling program for high-grade paper, mixed paper, cardboard, and aluminum cans. The pick-up of these items is provided free of charge by the local sanitary waste disposal company. The estimated number of pounds recycled in FY 1993 was 172,081. By initiating the recycling program, three dumpsters were removed from service and trash pick-ups were reduced from two per week to one per week. This resulted in a cost savings of $\$ 42,000$ per year.

Other accomplishments included elimination of a fuel-sample waste stream by procuring a filter device that allows the samples to be reused. At the Kirtland Operations office in Albuquerque, the ES\&H Department sponsored a "Chemical Amnesty Day" in which users were encouraged to discard obsolete or excess chemicals. This resulted in 1,900 pounds of hazardous materials being turned over to ES\&H for proper disposal. At the Remote Sensing Laboratory in Las Vegas, approximately 230 gallons of oil and 220 gallons of aviation fuel were transferred to the Nellis Air Force Base for recycling, and approximately 240 cubic feet of styrofoam peanuts were collected and recycled. At the Santa Barbara Operations office, two employee suggestion awards were granted for minimizing liquid mercury-containing waste and awareness training was conducted. 
Hazardous and nonhazardous wastes are managed in a manner that minimizes or precludes potential hazards to employees, the public, and the environment and that complies with DOE Orders, and federal, state, and local laws and regulations.

\subsubsection{Future Plans}

Future plans include maintenance of the program at its current level and annual review and updating (as necessary) of the EG\&G/EM WMin/PP Awareness Implementation Plan. EG\&G is also coordinating the use of the FlowGemini ${ }^{\circledR}$ computerized database to track hazardous materials and waste from cradle to grave. EG\&G/EM plans to continue as a leader in conducting PPOAs of its operations.

EG\&G/EM Remote Sensing Laboratory's Photo/Video Section has also requested funding to improve the wastewater treatment system by installing additional equipment for the purpose of reducing consumption of photochemicals, improving silver recovery efficiency, and reducing the quantity of pollutants discharged into the publicly owned treatment works (POTW). It is estimated that installation of this equipment will reduce photo fixer consumption by 50 percent.

\subsection{Raytheon Services Nevada}

RSN is under contract to DOE/NV to provide architectural and engineering services in Nevada in addition to M\&O services in the Pacific. The RSN Environmental Restoration and Waste Management (ERWM) Division presently provides services and products primarily to the DOE/NV AMEM programs.

\subsubsection{Current Status}

RSN's policy requires waste reduction to be a "prime consideration" in research activities, process design, facility design, and operations. RSN supports all DOE initiatives relating to WMin/PP pursuant to DOE Orders 4500.1, 5820.2A, and RCRA. RSN is committed to eliminate or reduce the total amount of hazardous and nonhazardous solid waste generated.

WMin/PP planning has been incorporated into all work plans, procedures, and sampling and analysis plans. RSN has appointed a WMin/PP Coordin?tor, who participates in WMin Task Force meetings and activities and is currently serving as PPAC chair during Calendar Year 1994. RSN has established an office recycling program for aluminum cans and paper 
products in all three of its Las Vegas office locations. In addition, all toner cartridges are returned for remanufacture to the DOE supply contractor. Personnel who are directly assigned to the NTS coordinate their WMin/PP efforts through the M\&O contractor (REECo).

Employee training has been a priority at RSN. A recent series of general employee training sessions have been accomplished for all RSN employees. This training depleted a backlog of required training to include WMin/PP Awareness Training. Training will continue for all new employees and any employees who were unable to participate in the initial series of classes. Refresher training will be accomplished annually.

RSN's WMin Suggestion Program is now part of the company's overall monetary award suggestion program. Any suggestions dealing with WMin/PP are automatically routed through the ERWM Division for initial evaluation. Personnel are eligible for monetary awards in addition to awards such as polo shirts, ball caps, and magnetic white boards.

\subsubsection{Future Plans}

The existing programs will continue to be maintained and expanded as funding is made available. The emphasis for RSN's future waste minimization program will be on conducting PPOAs and implementing waste minimization activities. Because most of RSN's activities are in DP, RSN is actively pursuing funding for conducting WMin activities in this area.

\subsection{Wackenhut Services, Inc.}

WSI is a subsidiary of the Wackenhut Corporation. The Corporation is one of the world's largest security and investigative organizations with offices in over 125 cities and 40 countries on six continents. The corporate headquarters is located in Coral Gables, Florida. WSINV provides security services through a contract with DOE/NV at the NTS and DOE/NV-related facilities in Las Vegas, Nevada.

WSI/NV provides support operations under interagency agreements pertaining to tunnel and underground tests, emergencies, and related functional activities. Environmental management programs are administered within WSINV by the ES\&H Section. The Section implements waste minimization programs to reduce the amount of hazardous and nonhazardous wastes generated and disposed. 


\subsubsection{Current Status}

WSI's security operations and activities at the NTS require utilization of small arms weaponry and training. The training aspect encompasses live fire on WSI/NV ranges. Weapons cleaning and maintenance operations generate nonradioactive hazardous wastes in the form of lead residue. The lead residue is removed from weapons in a cleaning process utilizing biodegradable solvents. After weapons cleaning, the solvent becomes contaminated with lead. A filtering process has been designed, developed, and installed. The process allows for recycling of cleaning solvent. The lead-contaminated filters are changed on an as-needed basis. Four of WSI/NV's seven waste streams are dedicated to lead contamination management. The three remaining waste streams consist of one waste stream for aerosol cans, one for mace, and one for batteries.

WSI eliminated the use of lead seals in its facility security program. The security seals are used for determination of persons accessing doors, hatches, and line-of-site pipes. The lead seals were substituted with aluminum seals in July 1991. WSI used approximately 100,000 seals per year. As a result, this initiative removed a significant quantity of lead waste from the environmental management program. The aluminum seals are more costly, 20 cents versus 6 cents per seal. The increased cost of over 300 percent is considered well justified by WSI/NV as it reflects the company's commitment to environmentally sound operations.

Formal paper and aluminum recycling activities have been in operation at WSI/NV since early 1991. Select employees at each of WSI's facilities have been designated Facility Managers for waste management/recycling purposes. These persons ensure recyclable paper and aluminum are collected and picked up by REECo. WSI's recycling activities are conducted in accordance with REECo's waste paper/recycling plan.

Toner cartridges from printers are also recycled by WSI/NV. This process entails the reuse of empty toner cartridges from certain computer printers. The cartridges are collected at a designated point. REECo, the lead contractor for this effort, collects the empty toner cartridges for reprocessing. The estimated cost savings is between 25 and 50 percent.

Although WSI/NV does not generate, transport, store, or dispose of radioactive or mixed waste, security-related functions are provided to the Area 5 RWMS. Within the RWMS are unclassified and classified sections. Access to the classified area is authorized by the DOE 
Safeguards and NTS Security Branch personnel through the WSI Supervision/Operations Section. Access to the facility is controlled by WSI security personnel unless otherwise directed. Administrative control of the classified area may be authorized by DOE. The unclassified portion of the RWMS is administratively controlled by REECo RWMS personnel.

WSI/NV owns and operates an incinerator as part of the company's contract performance. The incinerator is used for batch burning, which includes 75 percent paper and 25 percent plastics. The incinerator is fueled by natural gas/propane. Particulate emissions from the source are controlled by an afterburner. The permit, issued by the state of Nevada, allows burning eight hours per day, 109 days per year. Recently, hours of burning were extended from 576 to 872 total hours. WSI burns less than 600 pounds per week. Operation of the incinerator is managed within the parameters of the Clean Air Act, which authorizes the state of Nevada to administer air regulations.

\subsubsection{Future Plans}

Current assessments of WSI/NV waste data and policy indicate a goal of renewed emphasis on WMin/PP activities. Although WSI/NV's primary mission at the NTS is physical security, the reduction of hazardous waste is of importance and concern and should be reflected accordingly.

The additional reduction of hazardous waste is a goal of paramount importance and possibly requires additional emphasis in the area of technological feasibility. Currently, WSINV's waste stream of lead-contaminated liquid solvents has a filter system installed, as described above. The filtering system allows for reduction of lead contaminants from recyclable solvents. WSI/NV is currently examining the feasibility of additional recycling capabilities by changing to a different solvent and filter system. The proposed change has the capability of eliminating a liquid and two solid waste streams.

WSI/NV is currently conducting a feasibility study on the use of alternative ammunition for training purposes and weapons qualifications. This effort is in the interest of minimizing waste and protecting the environment. The ammunition reviewed as part of the study includes leadless ammunition and nonlethal ammunition. DOE/HQ presently has data acquired from other DOE ammunition studies. WSI/NV is acquiring these data and thus can prevent replicating previous studies. The acquired data will result in WSI/NV savings of 
approximately $\$ 20,000$ and DOE/NV savings of approximately $\$ 70,000$. Once testing of tungsten ammunition is completed by Oak Ridge in late FY 1994, WSI/NV will request to serve as a pilot test site for the ammunition testing. It is anticipated that the testing and evaluation project will be funded under the DOE/NV WMin/PP budget.

WSI/NV also plans to update its WMin/PP Implementation Plan in accordance with recentlyissued DOE/HQ guidance and applicable regulatory requirements. WMin assessments, surveillances, and evaluations will be conducted, as will PPOAs. WSI/NV also plans to continue training its employees through the WMin/PP Awareness Training Program developed by the WMin Task Force.

\subsection{IT Corporation}

IT Corporation is the Environmental Services Support Contractor (ESSC) for the NV ERP. IT Corporation provides scientific, regulatory, and technical support, and project and waste management services to NV ERP. IT Corporation develops work and sampling and analysis plans for several NV ERP subprojects, such as the Underground Test Area Operable Unit, RCRA Industrial Sites, Soils Media Operable Unit, Off-Site Locations Operable Units. portions of the Tonopah Test Range, and NV ERP Sites Inventory.

\subsubsection{Current Status}

IT has developed a WMin/PP Implementation Plan and conducts periodic self-assessments to measure employee participation and program goals. IT incorporates WMin/PP planning into all work plans, procedures, and sampling and analysis plans. IT has appointed a WMin/PP Coordinator, who participates in WMin Task Force meetings and activities and served as PP Awareness Committee chair during Calendar Year 1993. IT Las Vegas office has established an office recycling program for aluminum cans and paper products, which is provided free of charge by the local sanitary waste disposal company.

The IT WMin/PP Coordinator has participated in PPOA training, and other IT staff are scheduled to receive the training during FY 1995. The first NTS PPOA conducted under the DOE/NV standardized PPOA guidance is scheduled to be conducted at an NV ERP site. IT employees have participated in the emr oyee suggestion/awards program to a higher degree than originally anticipated. Many IT employees have also participated in community outreach 
activities, such as planning and participating in a cleanup at Lake Mead in conjunction with the International Coastal Zone Clean-Up Project.

IT presently purchases recycled materials whenever possible. All purchase requests are reviewed for employee health and safety and waste management considerations prior to purchase of the product. Non- or less-hazardous substitute products are purchased whenever possible. IT has also established a program for sampling and analysis of certain products where the product composition may be variable (such as bentonite used for drilling). This sampling and analysis helps ensure that products used will not contribute to the NTS hazardous waste stream.

\subsubsection{Future Plans}

IT plans to conduct at least one PPOA each year at an NV ERP subproject site. IT staff also plan to participate in at least one PPOA each year at a non-NV ERP site and to continue participation in WMin Task Force and PP Awareness Committee activities. IT plans to annually update its WMin/PP Implementation Plan. Future plans call for putting a suggestion awards program in place above and beyond the program participated in by all DOE NV contractors. Future plans also call for quarterly publication of an internal employee newsletter that publishes employee suggestions and WMin/PP ideas, participation in at least two WMin/PP national conferences each year, and implementation of additional affirmative procurement practices. 
Appendix A

Regulatory Drivers 


\section{Regulatory Drivers}

The DOE/NV Program is driven by the following:

- The Haza tous and Solid Waste Amendments (HSWA) to the Resource Conservation and Recovery Act (RCRA)

- The Emergency Planning and Community Right-to-Know Act (EPCRA)

- The Clean Air Act Amendments (CAA) of 1990

- Federal Facility Compliance Act (FFCA) of 1992

- The Pollution Prevention Act of 1990

- Nevada Administrative Code, Chapters 445 and 459

- DOE Orders 5400.1, 5820.2A, 5400.3, and 6430.1A

- Executive Order 12780, Federal Agency Recycling and the Council on Federal Recycling and Procurement Policy

- Executive Order 12088, Federal Compliance With Pollution Control Standards

- Executive Order 12856, Federal Compliance with Right-to-Know Laws and Pollution Prevention Requirements

- The Clean Water Act (CWA) of 1987

- Agreement in Principal between the State of Nevada and DOE

- DOE policies

- DOE radiological controi requirements

- Internal policies and best management practices 
Appendix B

Estimated Budget 
This appendix provides the budget estimate for conducting Waste Minimization and Pollution Prevention (WMin/PP) activities in support of U.S. Department of Energy Nevada Operations Office (DOE/NV). Budget estimates are provided for both Defense Programs (DP) and Environmental Management (EM).

For EM programs, funding estimates are provided under three levels, as directed by DOE Headquarters. These levels are decrement, target, and planning leveis. The decrement level is the least amount of funding and is that funding required to support a basic program that meets regulatory requirements. The funding requested under each program element is provided in Table B-1. The scope of work includes all site-wide activities that are predominantly associated with WMin/PP. The tasks include coordination of numerous contractors and waste minimization activities; facilitation and support for WMin Task Force and Pollution Prevention Awareness Committee; development of site-wide WMin/PP opportunity assessments and training; development of required regulatory reporting; creating and annually updating site WMin/PP plans, defining site-specific requirements for tracking materials from time of receipt to time of disposal. The budget estimate is based on requirements found in this plan and the 1994 WMin/PP Crosscut Plan. More detailed descriptions of items to be completed under each of the nine DOE Headquarters-defined elements are presented in Sections 4.0 and 5.0 of this document.

Budget estimates for funding from DP are presented for discrete, contractor-specific tasks, as shown in Table B-2. The scopes of work are for implementation of WMin/PP activities that are facility/waste-generator-specific. The task includes participation in the Toxic Release Inventory Voluntary 50/50 Reduction Program, conducting generator-specific pollution prevention opportunity assessments, purchase of capital equipment involving source reduction and recycling, and conducting environmentally sound procurement practices. Some activities may be one-time funding requests supporting implementation of a pollution prevention opportunity. 
Table B-1

EM Budget Estimates by Program Element

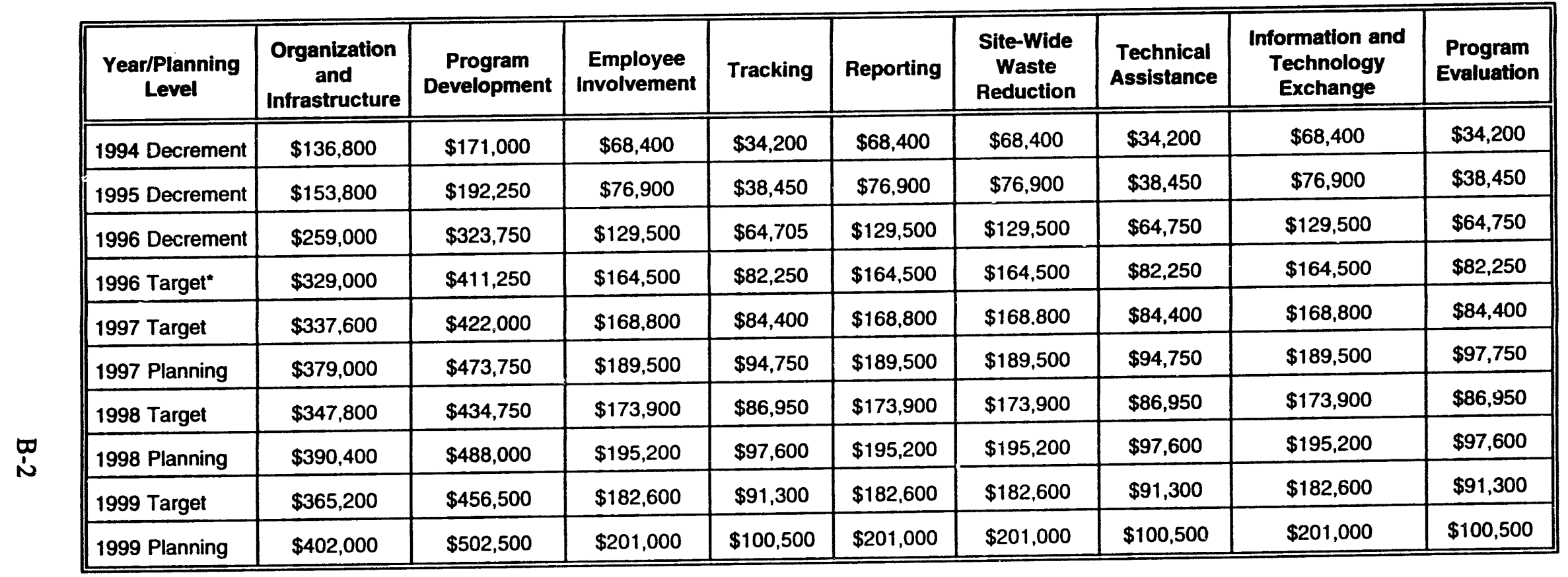

*In 1996 target = planning level funding 


\section{Table B-2 \\ Defense Programs Budget Estimates}

\begin{tabular}{|c|c|c|}
\hline Activity Scope & $\begin{array}{c}\text { Fiscal } \\
\text { Year }\end{array}$ & $\begin{array}{l}\text { Budget } \\
\text { Estimate }\end{array}$ \\
\hline $\begin{array}{l}\text { Provide data for } 17 \text { priority chemicals on TRI worksheet to } \\
\text { DOE/NV-EPD Program Manager; data for chemicals covered by } \\
\text { EPCRA Section } 313 \text {; TRI Form R, Part II provided to DOE/NV. } \\
\text { (Requested by REECo) }\end{array}$ & $\begin{array}{l}1994 \\
1995 \\
1996 \\
1997 \\
1998 \\
1999\end{array}$ & $\begin{array}{l}\$ 150,000 \\
\$ 154,000 \\
\$ 159,000 \\
\$ 163,000 \\
\$ 168,000 \\
\$ 173,000\end{array}$ \\
\hline $\begin{array}{l}\text { Develop and implement programs overseeing the use of } \\
\text { hazardous materials, hazardous constituent-emitting equipment, } \\
\text { and for evaluating opportunities to reduce solid waste at all } \\
\text { EG\&G/EM locations. (Requested by EG\&G/EM) }\end{array}$ & $\begin{array}{l}1994 \\
1995 \\
1996 \\
1997 \\
1998 \\
1999 \\
\end{array}$ & $\begin{array}{l}\$ 172,000 \\
\$ 181,000 \\
\$ 190,000 \\
\$ 199,000 \\
\$ 209,000 \\
\$ 220,000\end{array}$ \\
\hline $\begin{array}{l}\text { Improve the Remote Sensing Laboratory Photo/Video wastewater } \\
\text { treatment system by installing additional equipment of reducing } \\
\text { consumption of photochemicals, improving silver recovery } \\
\text { efficiency, and reducing the quantity of pollutants discharged into } \\
\text { the publicly-owned treatment works (POTW). This includes } \\
\text { installation of chemical regeneration equipment that will recycle } \\
\text { photochemicals containing ferrocyanides directly back into the } \\
\text { photo process; installation of electrolytic silver recovery system } \\
\text { for bleach fix and fixer solutions to reduce fixer consumption by } \\
50 \text { percent; installation of a pH pretreatment system and two cold } \\
\text { vaporatization units to treat photographic chemical waste streams } \\
\text { prior to POTW discharge; installation of ion exchange columns } \\
\text { and scrubbers to treat overflow from fixer process baths, } \\
\text { processor wash waters, and evaporator distillate; and elimination } \\
\text { of existing, less-efficient silver recovery systems. (Requested by } \\
\text { EG\&G/EM) }\end{array}$ & $\begin{array}{l}1994 \\
\text { (one-time } \\
\text { funding } \\
\text { request) }\end{array}$ & $\$ 366,000$ \\
\hline $\begin{array}{l}\text { Provide monthly and annual WMin/PP reports, update and } \\
\text { maintain WMin/PP implementation plan, set and obtain WMin/PP } \\
\text { goals, conduct (or participate in) WMin/PP opportunity } \\
\text { assessments, and conduct environmentally sound procurement } \\
\text { emphasizing toxic pollutant reduction. (Requested by WSI) }\end{array}$ & $\begin{array}{l}1994 \\
1995 \\
1996 \\
1997 \\
1998 \\
1999\end{array}$ & $\begin{array}{l}\$ 20,000 \\
\$ 20,500 \\
\$ 21,000 \\
\$ 21,500 \\
\$ 22,000 \\
\$ 22,500\end{array}$ \\
\hline $\begin{array}{l}\text { Conduct oversight of contractor activities, participate in WMin/PP } \\
\text { opportunity assessments with an emphasis on source reduction, } \\
\text { conduct inspections and surveillances of contractor activities to } \\
\text { ensure implementation of source reduction and recycling which } \\
\text { provides a return on investment. (Requested by DOE/NV } \\
\text { Environmental Protection Division) }\end{array}$ & $\begin{array}{l}1994 \\
1995 \\
1996 \\
1997 \\
1998 \\
1999\end{array}$ & $\begin{array}{l}\$ 39,000 \\
\$ 39,900 \\
\$ 40,800 \\
\$ 42,000 \\
\$ 43,200 \\
\$ 44,400\end{array}$ \\
\hline
\end{tabular}


Appendix C

Nevada Waste Minimization Policy 


\section{Nevada Waste Minimization Policy}

DOE policy requires waste reduction to be a "prime consideration" in rescarch activities, process design, and facility design and operations. It is the DOE/NV policy to support this effort and all DOE initiatives relating to waste minimization and pollution prevention awareness pursuant to DOE Orders 5400.1, 5400.3, 5820.2A; and the Resource Conservation and Recovery Act (RCRA). To this end, DOE/NV is committed to eliminate or reduce the total amount of hazardous, mixed, radioactive, and nonhazardous solid waste it generates.

DOE/NV targets elimination or source reduction of waste as the top priority by enhancing and continuing an aggressive program of identifying all processes that cause waste to first be generated. Once these processes are identified, available technologies will be applied to change the process design or substitute a benign agent in place of the waste generating agent. For those processes that currently have no applicable technologies to eliminate waste, DOE/NV will emphasize environmentally sound recycling programs over treatment, control, and disposal.

DOE/NV is dedicated to the development of a Pollution Prevention Awareness Program. Pollution prevention awareness will be the vehicle which brings waste minimization into the culture of the work place. Effective implementation of the Pollution Prevention Awareness Program will be ensured by training all personnel (from top management on down) regarding the benefits of eliminating and reducing waste generation. DOE/NV will strongly encourage contractors and users to study their areas of responsibilities and suggest ways to eliminate or reduce waste through a suggestion or incentive award program. DOE/NV will actively advertise the successes of waste minimization to demonstrate a proactive position and inspire further involvement by all contractors and user personnel.

DOE/NV views the Waste Minimization and Pollution Prevention Awareness Program as a critical tool that could eliminate or reduce the need for many programs which are currently required to regulate and report waste in the DOE system. DOE/NV recognizes waste minimization as the tool for DOE management to gain credibility for aggressively taking action to protect the environment, protect the workers health, and present a positive image to the public. DOE/NV is proactively monitoring the effects of what has taken place in the past and is correcting the unsatisfactory activities of the present. DOE/NV dedication to the resolution of waste generation will eliminate and mitigate future problems. 


\section{Appendix D \\ Waste Minimization Task Force Charter}




\section{D.1.0 Introduction}

U.S. Department of Energy Nevada Operations Office (DOE/NV) responsibilities for waste minimization operations reside in the Waste Management Division (WMD). This office is responsible for administering DOE/NV-wide policies and procedures for all waste minimization related activities. A task force has been formed to support WMD with waste minimization responsibilities.

This charter provides a description of the task force's purpose and functions. It is intended to provide guidelines and authority so that the task force can focus on areas of interest to DOE/NV as well as identify, through its own discussions, other areas that should be addressed.

\section{D.1.1 Purpose}

The Waste Minimization Task Force (WMTF) is to provide DOE/NV with expert input on waste minimization matters. This input is intended to provide insight based on the task force members' collective experience and knowledge. The WMTF is encouraged to communicate, coordinate, review, and obtain input from their organization's personnel who perform in the areas which are covered by the DOE/NV policy on waste minimization.

\section{D.1.2 Scope}

The scope of the WMTF includes all waste minimization activities. While the area of consideration is broad in scope, the task force should focus on the communication and awareness of the waste minimization program, the implementation of process waste assessments, and the evaluation of these assessments and the program.

\section{D.1.3 Functions}

The WMTF will provide support to WMD by:

a. Evaluate the performance of proposed waste minimization options and those which have been implemented;

b. Monitor the progress of the waste minimization program;

c. Identify problems being encountered in complying with waste minimization requirements and analysis of these problems, including recornmendations for resolving them; 
d. Recommend waste minimization goals and objectives;

e. Evaluate results of process waste assessments;

f. Evaluate the technical and economic feasibility of options to reduce waste generation;

g. Exchange of information for technology transfer, pollution prevention awareness, and training;

h. Evaluate and recommend DOE/NV recycling programs.

\section{D.1.4 Representative}

Representatives for the WMTF will consist of individual representatives from waste generating and waste management organizations. The responsibilities of the representatives are as follows:

a. Coordinate the implementation of their organization's Waste Minimization and Pollution Prevention Awareness Plan;

b. Provide information to the Waste Minimization Program Manager (PM) and the Waste Minimization Coordinator (WMC) for reports on waste minimization (annual and biennial reports required by the DOE, U.S. Environmental Protection Agency [EPA], and state);

c. Report on the status of their organization's waste minimization and pollution prevention awareness goals and objectives;

d. Provide information to the WMC, the quarterly DOE/NV Waste Minimization and Pollution Prevention Awareness Newsletter;

e. Perform self-assessments on their organization's waste minimization program:

f. Maintain an up-to-date list of waste streams and generating processes by their organization;

g. Revise and ensure currency of their organization's Waste Minimization Implementation Plan;

h. Provide the Waste Minimization PM and WMC with milestone schedules (including process waste assessment and the results of such assessments) and status of implementation of plans; and

i. Ensure a Pollution Prevention and Awareness Program is developed and implemented in their organization. 


\section{D.1.5 Facilltator}

The Facilitator for the WMTF will be the WMC. The responsibilities of the WMC are as follows:

a. Verify the implementation of the DOE/NV Waste Minimization Plan;

b. Provide DOE/NV with a detailed task plan(s) on annual budgets for waste minimization efforts, including a breakdown by activity and contractor/user;

c. Coordinate the efforts of the WMTF;

d. Notify WMTF members of any upcoming waste minimization meetings, workshops, conferences, etc.;

e. Prepare minutes of WMTF meeting. Minutes will include activities for the past and succeeding quarter, submitted within two weeks after the meeting to the Director, WMD;

f. Provide WMTF members with meeting agendas at least one week prior to the meeting;

g. Compile the data and prepare the annual report to DOE/HQ and biennial report to EPA; and

h. Provide monthly reports to the Waste Minimization PM including, but not limited to, highlights, meetings attended, and milestones completed.

\section{D.1.6 Operational Support}

Operational support will be provided by WMD through the Waste Minimization PM. The $\mathrm{PM}$ is responsible for determining the budget allocations for waste minimization activities as well as defining the priorities of the WMTF. All WMTF recommendations will be reviewed by the PM for final concurrence. The PM will conduct surveillances of waste minimization activities. The WMC and PM will work closely together to implement the DOE/NV Waste Minimization Plan and establish a successful program. Guidance for a compliant and successful program will be the responsibility of the PM.

\section{D.1.7 Meetings}

WMTF meetings will be held at least quarterly. The time, date, and location will be determined at the previous meeting. Additional meetings may be called at the WMC or PM's discretion. Monthly meetings will be held between the WMC, PM, and other DOE/NV representatives. 


\section{D.1.8 Agenda}

Agenda items and topics for regular meetings should be submitted to the WMC for review.

\section{D.1.9 Modification}

This charter, after fully enacted, may be revised or modified by the PM and WMC with the concurrence of the current WMTF members. 
Nick C. Aquilina, Manager

\section{Copies}

DOE/Nevada Operations Office

Post Office Box 98518

Las Vegas, Nevada 89193-8518

Warren D. Black, Program Manager

U.S. Department of Energy

12800 Middlebrook Road

Germantown, Maryland 20874-1290

Angela P. Colarusso

Waste Minimization Program Manager

DOE/Nevada Operations Office

Post Office Box 98518

Las Vegas, Nevada 89193-8518

G. Leah Dever

Deputy Assistant Manager for

Environmental Restoration and

Waste Management

DOE/Nevada Operations Office

Post Office Box 98518

Las Vegas, Nevada 89193-8518

Cindy L. Dutro

Waste Minimization Program Coordinator

Reynolds Electrical \& Engineering Co., Inc.

Post Office Box 98521, M/S 428

Las Vegas, Nevada 89193

Donald R. Elle, Director

Environmental Protection Division

DOE/Nevada Operations Office

Post Office Box 98518

Las Vegas, Nevada 89193-8518

Joseph N. Fiore

Acting Assistant Manager for

Environmental Restoration and

Waste Management

DOE/Nevada Operations Office

Post Office Box 98518

Las Vegas, Nevada 89193-8518

Carl P. Gertz, Director

Waste Management Division

DOE/Nevada Operations Office

Post Office Box 98518

Las Vegas, Nevada 89193-8518 
Kent Hancock. Director

Waste Minimization Division

U.S. Department of Energy

EM-352

12800 Middlebrook Road

Germantown, MD 20874

J. E. Henderson

Raytheon Services Nevada

Post Office Box 95487

Las Vegas, Nevada 89193-5487

Roger Herrod

Wackenhut Services, Inc.

Post Office Box 168, M/S 787

Las Vegas, Nevada 89023

Terry S. Holmes

Reynolds Electrical \& Engineering Co., Inc.

Post Office Box 98521 , M/S 737

Las Vegas, Nevada 89193

Roger Jacobson

Desert Research Institute

Post Office Box 19040

Las Vegas, Nevada 89132-0040

Asha Kalia

Science Applications International Corporation

Yucca Mountain Project

101 Convention Center Drive

$\mathrm{M} / \mathrm{S} 517 / \mathrm{T}-11$

Las Vegas, Nevada 89109

Jeff Lewis

Los Alamos National Laboratory

Post Office Box 0, M/S 900

Mercury, Nevada 39023

Terre Maize

IT Corporation

4330 S. Valley View, Suite 114

Las Vegas, Nevada 89103

John Marchetti, Executive Officer

Pollution Prevention Program

DP-34

U.S. Department of Energy

19901 Germantown Road

Germantown, MD 20585

Barry Pritchett

Post Office Box 208

Mercury, Nevada 89023-0208 
Lawrence Livermore National Laboratory

Post Office Box 45, M/S 777

Mercury, Nevada 89023

Amo Sanchez

EG\&G Energy Measurements, Inc.

Post Office Box 1912

M/S $570 \mathrm{Cl}-105$

Las Vegas, Nevada 89125

Peter Sanders

Environmental Protection Division

DOE/Nevada Operations Office

Post Office Box 98518

Las Vegas, Nevada 89193

Lt. Colonel Edward Tullman

USAF/DOE Liaison Office

Post Office Box 98518, M/S 505

Las Vegas, Nevada 89193

U.S. Department of Energy

Office of Scientific and Technical Information

175 Oak Ridge Turnpike

Post Office Box 62

Oak Ridge, Tennessee 37831

Lynn Wade, Director

Western Operations Division

U.S. Department of Energy

12800 Middlebrook Road

Germantown, Maryland 20874 

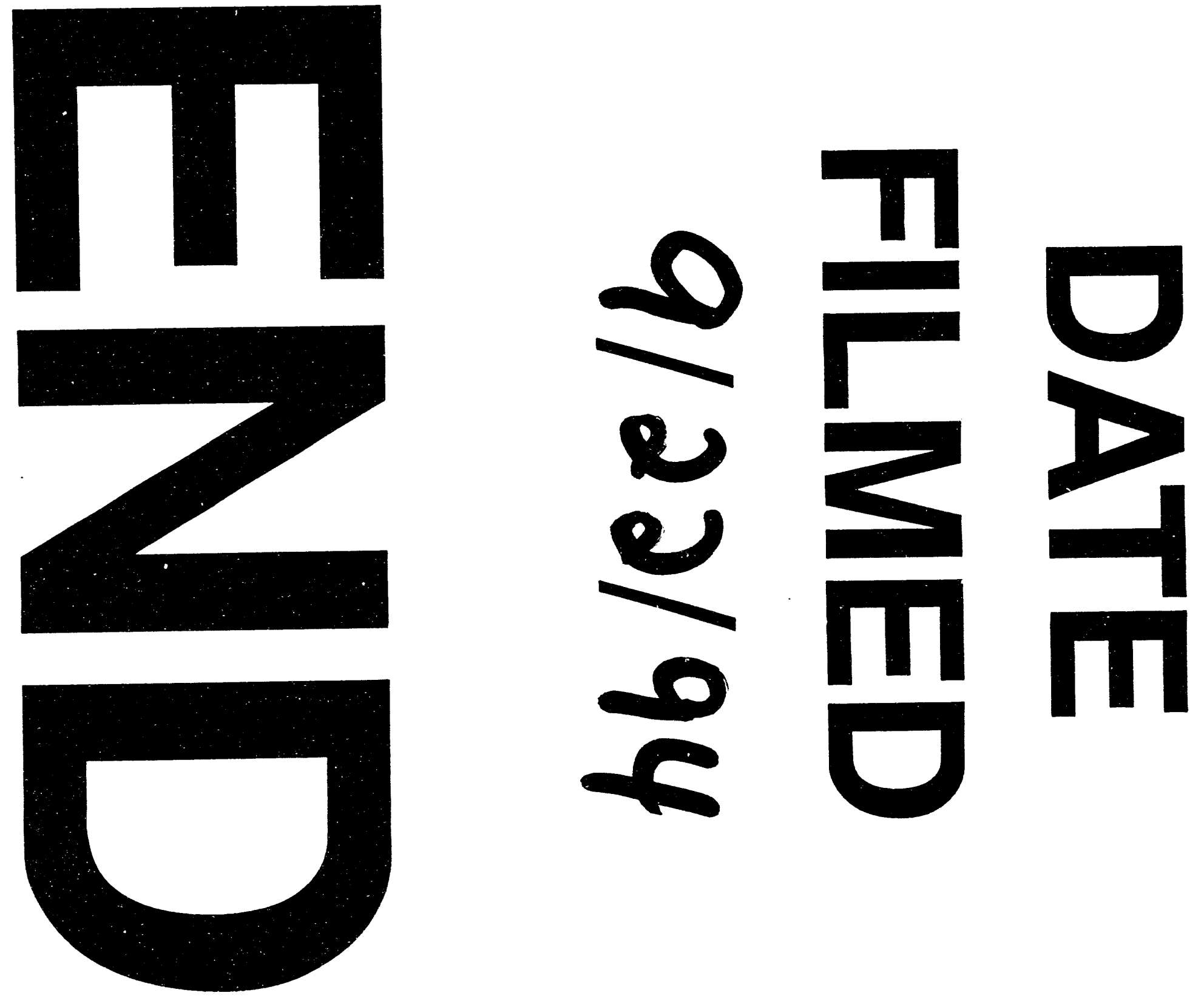
